\title{
CORPORATE STRATEGY DEVIATION AND INSTITUTIONAL INVESTOR RECOGNITION: COMPLEX NETWORK-BASED AND GRAPH CLUSTERING ANALYSIS
}

\author{
Chunyan $\operatorname{LIN}^{1}$, Jia LIU ${ }^{*}$, Peide LIU ${ }^{2 \#}$ \\ ${ }^{1}$ School of Statistics, Shandong University of Finance and Economics, Jinan, 250014 Shandong, China \\ ${ }^{2}$ School of Management Science and Engineering, Shandong University of Finance and Economics, \\ Jinan, 250014 Shandong, China
}

Received 15 February 2021; accepted 16 May 2021; first published online 26 October 2021

\begin{abstract}
In this paper, the quantitative analysis is implemented on the relationship between strategy deviation of listed firms and institutional investors' recognition. For research methodology, financial complex networks and clustering techniques are employed to measure the de-gree of recognition by creating links to the common stockholding behaviour of institutional investors. Besides, quarterly panel data from 2006 to 2020 are constructed for an innovative study of the degree of recognition of institutional investors' strategy deviation of listed firms under different innovation fields, firm properties, and market style heterogeneity and asymmetry. The stability test is conducted by the transformation of the measures and methods, thereby effectively avoiding the "cluster fallacy". We validate the mechanism by which the differences in strategic choices and propensities of listed firms affect capital market recognition, and enrich the microscopic research perspective and methodology on related issues.
\end{abstract}

Keywords: complex networks, generalized clustering, corporate strategy, institutional investors.

JEL Classification: G23, G32, G41, O16.

\section{Introduction}

The tragic lessons learned from the sudden collapse of some high-performing large companies due to poor risk management and regulation in this century (Enron, WorldCom, CNOOC, etc.) have caused significant losses to investors and other stakeholders, and have drawn the attention of the global business, academic and political communities. Many countries have adopted new laws, regulations and listing guidelines to strengthen corporate governance and reduce risk management. Among the many business risks, strategic risk has been an important part of corporate risk. Corporate strategy involves a set of decisions and actions taken by a corporate entity to improve its core competencies and gain an advantageous

${ }^{\star}$ Corresponding author. E-mail: 191114002@mail.sdufe.edu.cn

\#Corresponding author. E-mail: peide.liu@gmail.com

Copyright (c) 2021 The Author(s). Published by Vilnius Gediminas Technical University

This is an Open Access article distributed under the terms of the Creative Commons Attribution License (http://creativecommons. org/licenses/by/4.0/), which permits unrestricted use, distribution, and reproduction in any medium, provided the original author and source are credited. 
position in the competition. It has been shown that corporate strategic decisions are directly reflected in financial disclosures and affect the characteristics of corporate accounting information. Successful corporate strategies can lead to superior financial performance (Buzzell \& Gale, 1987), which indirectly leads to less surplus management behaviors and higher quality of accounting information ${ }^{1}$ (Keating \& Zimmerman, 1999; Kinney \& McDaniel, 1989). The implementation of corporate strategy can be externally perceived through financial information disclosure (Kothari et al., 2002). In the capital market, institutional investors have higher expertise and information advantages, and their research and operation have a guiding and leading role for investors, who are important subjects in market transactions. The typicality and representativeness of how they interpret and screen the strategy deviation of companies is the question of whether the specific implementation of corporate management decisions can influence investors' decisions after the statements are expressed, which is related to the correlation between the internal corporate management strategies, decision-making risks, and the external capital market (Cappa et al., 2020). The study of this issue connects corporate governance strategies with financial markets. The latest scientific research shows that the sustainability of financial models is related to the sustainability of society as a whole (Ziolo et al., 2021), so it is of practical importance to study the external financial effects of corporate strategies.

Generally speaking, companies choose conventional strategies to ensure experience and stability, but in order to adapt to changes in the external environment and gain additional competitive advantages, companies may adopt a deviation from the industry's conventional approach to differentiate their business, i.e., corporate strategy deviation. At present, when measuring the differences in the strategy deviation of enterprises, the degree of deviation from the industry average is mostly used. And the larger this deviation is, the more likely the enterprises are unable to use their original industry experience and development laws to explain and characterize their strategies, and the greater the degree of information asymmetry between enterprises and external stakeholders (Carpenter, 2000). This asymmetry of information has to be taken into account when studying the relationship between corporate strategy and external relations, for example, between upstream and downstream supply chains of companies (Gao et al., 2020), not to mention that we need to focus on the sensitive area of capital markets. However, most of the current relevant studies focus on whether the strategic information itself is relevant to the value of the firm; for the capital market external to the firm, some of the literatures investigate the role of corporate strategy in influencing accounting information for stock pricing; for the stakeholders outside the firm, many studies focus on third-party perspectives, such as auditors and analysts. Then, for institutional investors, the main research of this paper includes whether the increase in operational risk and

\footnotetext{
${ }^{1}$ In the capital market, the FASB issued Concept Release No. 1 in 1978, when the financial accounting aiming to be useful for decision making was changed to providing investors with the information that is more relevant to decision making, the institutional investors and standard-setting bodies continued to emphasize the external decision-making role of accounting information. The AICPA (1994), CICA (1995), ICAEW (2000) and FASB (2001) and other standard-setting bodies also suggested that in order to improve the quality of financial reporting information, and make investors' decisions more efficient, companies should disclose other information in the value-creation process that is not recognized by the accounting system. That is, the financial perspective has to serve the investment decision, internal corporate strategic decisions influence external investor decisions, and accounting disclosures serve investors.
} 
information asymmetry caused by differences in corporate strategy deviation significantly increases the risk, monitoring cost and transaction cost of institutional investors' shareholding, and reduces the return of institutional investors' shareholding and the incentive of institutional investors to hold company shares. The purpose and interest of this paper focuses on whether deviation in the strategic orientation of enterprises can elicit recognition from external institutional investors, specifically what categories of strategy deviation are recognized and held by them (asymmetry between the two), thus providing the enterprises with a kind of empirical reference between strategy and financing. Besides, related studies, especially those for the Chinese market, are relatively few, and the study of institutional investors' recognition level lacks accurate methods.

In this paper, a total of 54,264 observations are used as the sample to examines the impact of corporate strategy deviation on the recognition of institutional investors in the financial capital market, which are obtained from 952 non-financial listed enterprises in Shanghai and Shenzhen A-shares from 2006 to 2020. It is found that the greater the difference of the strategy deviation implemented by the firm from the industry norm, the lower the recognition of the firm in the capital market where institutional investors are more adept at information acquisition and analysis. For example, the deviation of the firm's strategy deviation results in the willingness of institutional investors to hold, and signs of institutional holdings reduction. Through further research, it is found that, firstly, there are differences in the sensitivity of institutional investors to hold reduction in three key areas in terms of the differences in strategy deviation of enterprises, that is, production and $\mathrm{R} \& \mathrm{D}$, marketing and investment, and finance and financing; secondly, when facing listed enterprises with different property rights nature and investment background, the sensitivity of institutional investors to hold reduction also varies, and its sensitivity is particularly sensitive to the listed enterprises with the background of state control or investment; thirdly, when facing diversified market states, the moderating effect of market style is different, though institutional investors, as a whole, are not sensitive to different market reactions, bear markets and shock markets still make them more cautious, and there is a market moderating effect. However, the group of institutional investors among them is more sensitive to the market, in addition, both direct and indirect effects show a significant negative effect. In summary, according to empirical studies, differences in corporate strategy deviation reduce the willingness of institutional investors to hold, with specific mechanisms that are asymmetric in nature.

\section{Literature review}

\subsection{The impact of corporate strategy deviation on operational risk from within firms}

Firms face business risks in their operations (Blanc Alquier \& Lagasse Tignol, 2006; Dvorsk et al., 2021; Salehi \& Ghasempour, 2021; Li et al., 2021), and even in management and decision-making itself (Salehi et al., 2020a, 2020b; Salehi \& Arianpoor, 2021). In early studies Prahalad and Hamel (1990) argued that uniqueness and differentiation will lead to excellent corporate performance, sustained competitive advantage, and are important ideas for strategic management. And while the business press usually argues that change is in the best interest 
of shareholders, later studies by Chen and Miller (1994), Geletkanycz and Hambrick (1997), Rajagopalan and Spreitzer (1997), have shown that there is no strategic deviation from the norm and firm performance causality, nor does it enhance competitive advantage. Especially in highly uncertain industries, the relationship between the two is even negative. From the current literature, it is often argued that deviations from business strategy led to enhanced performance volatility, increased operational risk, and increased risk of corporate default and stock price collapse. Rajagopalan (1997) argues that aggressive corporate strategies engage more aggressively in new product and market development, performance is more volatile, and internal incentives need to be based on market performance rather than accounting performance to encourage management to take risks. Carpenter (2000) mentions that differences in corporate strategies are a choice of operating management and are related to the compensation incentive approach and structure, and the relationship between the two when firms perform differently. There is a correlation between strategic deviations and the internal governance structure of the firm. Chatterjee and Hambrick (2007), Tang et al. (2011) argue that when the difference in corporate strategy deviation is large, firms tend to lack practical experience in the same industry in their operations, and exploratory business activities are prone to extreme excellence or extreme failure. Besides, their operating performance is more volatile and relative to other firms in the same industry. Bentley et al. (2013), Higgins et al. (2015) and Habib et al. (2017) argue that the more aggressive corporate strategic decisions, the higher the degree of tax avoidance, the more aggressive the tax avoidance tactics, and the more willing firms are to take the risks and uncertainties that aggressive tax avoidance may bring. Also, corporate strategy deviations affect the quality of accounting information and surplus management, leading to stronger audits, as well as a higher likelihood of stock price collapse with the implementation of aggressive corporate strategies. Zhou and Wan (2017) propose that the differentiation in corporate strategy deviation may result in a coordination burden within the firm, that is, the diversification of strategies intensifies the conflict between the scale and scope of economy, and increases the burden and risk of the firm's procurement department. In addition, the diversified corporate strategies bring management, organizational design complexity challenges. And in corporate mergers and acquisitions, deviating financial strategies can prevent further expansion and be costly (Henry et al., 2019). Of course, this is not to deny reform and innovation in firms; management's enterprising spirit and innovative ability is a driving force for firm development (Chebbi et al., 2020), but we are exploring strategic behavior that deviates from industry norms.

\subsection{From the perspective of the external investor market, stakeholders have information asymmetry in the interpretation of corporate governance decisions within the firm}

The strategic tendency of companies to deviate from the industry norm tends to increase the demand for financing, but under the influence of information asymmetry, it is difficult for investors to distinguish whether the strategic deviation is a "reform and innovation" or a "deviation from the norm". This has an impact on the results of auditors' reports, analysts' attitudes, and investors' acceptance. It is difficult for external stakeholders to use the indus- 
try's conventional standards to evaluate companies with large strategic differences compared to companies with conventional industry strategies. Firstly, in terms of objective corporate needs, Ittner et al. (1997), Miles and Snow (2003) argue that aggressive corporate strategies constantly develop new products, seek new markets, and invest more in R\&D, and are therefore more likely to be in financial distress due to inadequate cash flow. They have a higher need for financing from external capital markets than other firms. Especially when changes in monetary policy affect the strategic choices of firms, firms with aggressive strategies have a greater need for a continuous supply of funds for their R\&D and market development activities (Bates et al., 2009). The main role of capital markets is to raise funds through different institutions, where securities financing is an effective way to obtain long-term funding for listed companies, a process that cannot be done without institutional investors (Algaeed, 2021). Secondly: in terms of the reactions of various stakeholders in the capital market, Bentley et al. (2013) argue that the auditor, as an external independent third-party service provider, the degree of aggressiveness of the firm's strategy is positively related to the firm's financial irregularities. And the more aggressive the corporate strategy is, the greater the auditor's workload, the more cautious the auditor is, and the higher the audit fees charged. In addition, as a medium between investors and listed companies, securities analysts' research reports represent the capital market's attitude and view on listed companies to a certain extent. Benner (2010) found that analysts pay attention to information such as strategic characteristics of companies, and technological changes of companies increase analysts' attention, and they tend to focus more on existing technologies than on radical change. More importantly, the capital market, as an external market for firms, has market participants who are the shareholders of firms and are important stakeholders of listed firms. Suijs (2008) and Lara et al. (2011) argue that when firms operate at higher risk, the necessary payoff required by investors for taking risk is relatively higher and the cost of equity capital of firms is higher. The choice of investment approach by firms is largely influenced by the bias of financial strategies, and aggressive debt ratios can have an impact on the choice of financing (Chauhan \& Huseynov, 2016). And due to the presence of investor speculation, even innovative strategies with positive results do not increase stock liquidity to the detriment of private companies (Wen et al., 2018). Thirdly: in capital markets, there is both information asymmetry among investors and investors' rational expectations about the information asymmetry between themselves and others, both of which affect their trading behavior. Jin and Myers (2006), Hutton et al. (2009) suggest that the higher the information asymmetry of firms, the lower the information content of stock prices and the more synchronous stock price fluctuations. And corporate managers may conceal off-balance sheet negative information, and the accumulation and release of the negative effects of this information can trigger a stock price crash (Kothari et al., 2009). Even that biased surplus management and tax planning by corporate authorities also increase information asymmetry, which is related to analysts' coverage, and that increase investors' uncertainty about future profitability, which may reduce corporate value even with an aggressive tax strategy that portrays an image (Chen \& Lin, 2017; Park \& Hee, 2017). And for corporate authorities, aggressive innovation strategies tie up large amounts of cash flow, while opportunism may come at the expense of shareholders, and aggressiveness makes the outcome further and further from the initial goal (Shaikh \& O’Connor, 2020). 
Through literature analysis, it is found that when facing this problem, in general, both Chinese and foreign scholars currently believe that the same industry deviation in the implementation of corporate strategy may increase business risks internally, and intensify information asymmetry externally (Carpenter, 2000; Jin \& Myers, 2006; Hutton et al., 2009; Kothari et al., 2009; Chen \& Lin, 2017). However, following problems still exist in the research on the differences of corporate strategy deviation and institutional investors. Based on previous literature combing, the main research gaps: firstly, there is less research on the specific measurement issues related to institutional investors and in association with each other; secondly, the research data is based on annual panel data, however, the recognized attitudes and behaviors of the capital market change frequently, therefore, more high-frequency and detailed data are needed; thirdly, there is a lack of more detailed exploration and research. Based on the thinking and theoretical foundation provided by the existing literature, this paper conducts further exploration, with the main contributions as follows:

- First: Technically, the prevalence and grouping of institutional investor recognition are measured using complex networks and clustering;

- Second: In terms of data, this paper uses quarterly data combined with financial network data for the measurement, which enables a more precise microscopic search for patterns;

- Third: In terms of content, a more detailed study of small samples reveals that the relationship between differences in corporate strategy deviation and institutional investor recognition is asymmetric across strategic areas, different corporate properties, and different market styles.

\section{Mechanism analysis and research hypothesis}

At this stage of strategic management and institutional theory, there is a conflict of opinion as to whether corporate strategy and management should be deviation or integration, a question that has never been decided. The question of how a firm can be "very much like" and yet "different" from its peers in a market state (Zhao et al., 2017). Specific theoretical perspectives from an institutional perspective are:

- First: When industries are highly structured, they can generate normative forces that lead to organisational homogeneity (DiMaggio \& Powell, 1983);

- Second: Concerned with legitimacy and effectiveness, organisations gain legitimacy by adhering to norms, avoiding punishment and having similar cultural patterns among peers (DiMaggio \& Powell, 1991);

- Third: The institutional theory perspective has been used to study for-profit firms in competitive markets (Haunschild, 1993; Haveman, 1993), creating a bond with strategic management, and more attention has been paid to the theoretical conflict between institutional norms and strategic operations.

- Fourth: The "strategic balance perspective" (Zuckerman, 2016) places firms between deviation and integration, mitigating theoretical conflicts.

Of course, this paper does not empirically demonstrate this paradox: the relationship between strategic deviation in firms and growth, firm performance, and industry competition. We focus on the relationship between such differences within firms and the recognition of 
external institutional investors. Corporate strategy deviation refers to the strategies and series of behaviors that are developed and adopted by the decision makers from the company's own perspective in order to improve their level of competition, and maintain a competitive advantage in the industry and market. In the early strategic management, it is believed that corporate strategy could be effectively planned to achieve more certain results. The entry of a company into a new product area or a new geographical area can be based on different explanations, such as the improvement of the efficiency of resource utilization, risk diversification, and promotion of market competitiveness. Unfortunately, with the deepening of research of theories and the practical activities of strategy, the controversy of strategy theory starting from planning continues, and the research on the riskiness, consequence and effectiveness of enterprise strategy choice gradually become hot. Firstly, it has to be decided whether the corporate strategy can be measured by the consequences of the implementation, as a way to illustrate the difference before and after the implementation of that strategy. In this paper, the measurement of corporate strategy is based on modern strategic management theory. And the degree of deviation from the average strategic pattern of the industry is utilized for the measurement of the objective elements reflected in the financial statement disclosure information when the strategic choice is made, through the allocation of resources and specific implementation, and based on three major aspects widely involved in the corporate strategic operations. The three key areas and six dimensions are divided into two types, i.e., the theoretical and data-based measures of differences in corporate strategy deviation. The second refers to the impact of corporate strategy deviation on itself after implementation, which, according to the previous studies, includes the impacts on corporate performance, corporate value, surplus management, accounting information quality, executive power constraints, corporate overinvestment and business risks. The third represents the impacts on the external market and external investors when corporate strategy is implemented, including third-party auditors and analysts, corporate creditors and corporate investors, etc. The impact of corporate strategy on the external market is studied through this stakeholder group. In this paper, we focus on the recognition of institutional investors who are important leaders in the capital market when the fermentation of corporate strategy deviation is implemented (Figure 1).

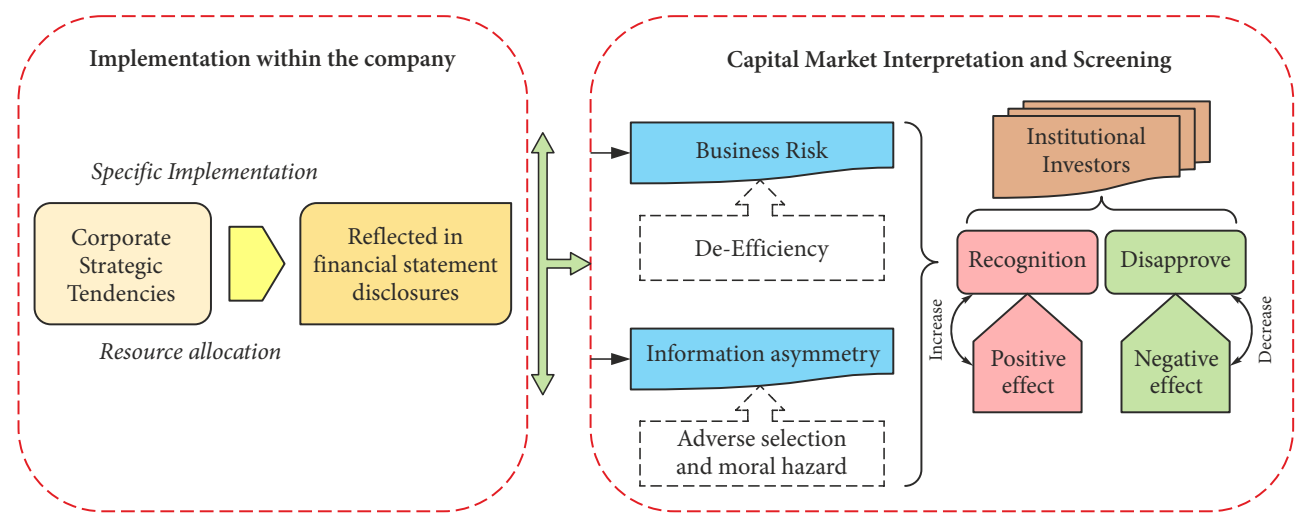

Figure 1. Mechanistic transmission diagram of corporate strategic deviation and institutional investor recognition 
As an important link to the external capital market, institutional investors' approval has great practical significance for the success of corporate strategy, stock price movement and market value.

Firstly, the greater difference in a company's strategy deviation, the greater its business risk. Conventional strategic patterns in an industry are developed and verified over a long period of time, and generally effective in resisting external risks. Deviation from the conventional strategic model requires higher cost of experimentation in exploring strategic decisions, and increases the risks faced by enterprises. Secondly, based on the analysis from the perspective of the external rule of law environment, enterprises are more familiar with the relevant industry systems and policies, which helps enterprises to reduce the risk of litigation under the industry's conventional strategic model. On the contrary, the greater the difference in strategy, the less familiarity with laws and regulations as well as institutional policies related to the new field, which may significantly increase the probability of corporate violations. Thirdly, in the case that a strategic model that is not proven in the industry is chose, the efficiency of a company's operations may be reduced. Therefore, enterprises need to deploy resources to the new strategic model, and if the old and new strategic models are far apart, the original resources may not be reused, or used under lessened efficiency. Fourthly, the enterprise is the first to choose a new strategic model, which tends to deflect the opinions of industry experts, and will increase the associated costs and risks. Therefore, Hypothesis 1 is proposed.

H1: The relationship between corporate strategy deviation and institutional investors' approval is negative, i.e., broadly speaking, institutional investors do not approve of firms' strategy deviating from the industry average strategic model.

However, corporate strategy deviation appears, and specific strategic behaviors may not be the same. For example, Das et al. (1998) argued that capital markets reflect positively when firms make strategic alliance announcements, while Doukas and Switzer (1992) suggested that even firms' profits are declining, their firms' capital markets still reflect positively when they announce new R\&D project decisions. But Cazavan-Jeny and Jeanjean (2006) find that capitalized R\&D is negatively related to stock prices, meaning that investors show a negative reaction to capitalized $R \& D$. Only smaller firms with higher leverage, lower profits and fewer growth opportunities can be successful in implementing this strategy. This means that even for the same strategy, different focuses may lead to different conclusions. It is found through various related studies that the capital market response caused by different focuses on different areas of corporate strategy varies. Besides, the institutional investors must view the market from their own perspective of analysis and investment strategy, therefore, when institutional investors face different focuses on corporate strategy tendencies, their specific recognition perspective needs further analysis. Therefore, Hypothesis 2 is proposed.

$\mathrm{H} 2$ : Institutional investor recognition of listed firms with different ownership properties is asymmetric.

Existing studies suggest that the increase of information asymmetry due to strategic deviation presents the main reason why strategic differences have their impact on corporate stakeholder behavior (Jin \& Myers, 2006; Hutton et al., 2009; Kothari et al., 2009). The 
greater the corporate strategy deviation, the stronger the degree of information asymmetry between the firm and its external stakeholders. The reason is that the greater the strategic differences of a firm compared to the norm, the more difficult it is to explain them based on the original industry experience and development laws, which will increase the degree of information asymmetry of the firm. Information asymmetry is an important reason for the low efficiency of capital market investment, in this case, alleviation of information asymmetry and enhancement of information communication inside and outside the firm are the key factors to improve the efficiency of capital allocation. Among them, the degree of information asymmetry of firms can be influenced by internal micro factors, such as corporate governance mechanisms and managerial characteristics. As per the data analysis of the total sample in this paper, $67.54 \%$ of the firms have state-owned background, and it is worth of further exploration of whether this category of firms receives the same market response as other firms when there is a difference in strategy deviation. For institutional investors, the increase of the degree of information asymmetry varies due to different causes, including the different aspects in strategy deviation of enterprises, the different backgrounds of enterprises and the nature of shareholdings, the increased risks, supervision costs and transaction costs associated with increasing institutional investors' shareholdings. However, all above causes will result in the reduction of the returns of institutional investors' shareholdings, and the weakening of the basic conclusion that institutional investors' motivation to hold company shares remains unchanged. In this case, Hypothesis 3 is proposed.

H3: There is an asymmetry between the strategy deviation of listed firms with different ownership properties and the recognition of institutional investors.

When studying the recognized attitudes of institutional investors toward the capital market, it is necessary to consider the changing environment of the Chinese securities market. In general, the institutional investors have strong capabilities in terms of information acquisition and analysis, who therefore adopt differentiated investment or position strategies in bull, bear and shock markets with different degrees of dissemination and inflation of idiosyncratic information; the institutional investors pay more attention to the bull market state under optimism, while when the bear market is approaching, the market often falls into the state of panic, and institutional investors may find it difficult to focus directly on corporate strategy; in the case that the market is in a state of shock, the institutional investors are most likely to be highly sensitive to the differences in corporate strategy deviation. However, head or conglomerate institutional investors may still be able to perceive this business risk on a rational and consistent basis thanks to their higher maturity and stability. Besides, the moderating effect of the market state variable varies for institutional investors' recognition due to differences in business risk, information asymmetry, and psychological settings of panic thresholds. Therefore, Hypothesis 4 is proposed.

H4: There is an asymmetry between corporate strategic deviation and institutional investor recognition when faced with different market styles. 


\section{Materials and methods}

\subsection{Measure of strategy deviation of listed enterprises}

Specifically, the strategy deviation of listed enterprises refers to the deviation of their chosen strategies from the average level of strategic patterns in their industries. There are two broad approaches for the measurement in the research field of strategic management, one is Bentley et al. (2013), Miles et al. (1978) employs extreme strategy classification at the time of strategy study, and classify corporate strategy into offensive, defensive and analytical models. Though this method is available for specific business models of firms, it fails to capture the changes in corporate strategy well when using panel data for the study, and the data classification is relatively coarse. The other is the degree of deviation of corporate strategic choices from the industry average strategic pattern used by Geletkanycz and Hambrick (1997), Tang et al. (2011). That is more suitable for the study involved in this paper problem, which can directly correspond to the financial situation and strategic risk faced by firms when they deviate from the mean.

Corporate macro-strategy can be reflected in specific business activities, therefore, the main idea behind the measurement of the strategy deviation of the company is that the strategy deviation of the company will be reflected in the financial data of the company through the allocation of strategic resources. Therefore, it can be seen that this indicator refers to a measure of the strategy put into practice, which has a greater advantage than qualitative management's ideas and plans (Geletkanycz \& Hambrick, 1997). Based on this idea, its distribution is reflected in three key areas, such as production and R\&D, marketing and inputs, finance and financing and six dimensions, as shown in Table 1.

Firstly, the field of production and R\&D is an important strategic input for the future growth of the enterprise, which is reflected in the enterprise's internal capital investment and production capacity expansion, and often reflects the formation of capital assets; while the field of marketing and input is an indispensable enterprise operation process, which is reflected in the enterprise's external publicity and expenses, and often reflects the cost loss in the operation process; the area of finance and financing is the largest resource mobilization of business operations and development, which is reflected in the financial leverage of the enterprise, and often reflects the layout of the financial situation of the balance of the relationship between net assets and liabilities. Secondly, a total of six dimensional indicators are utilized to reflect the three key areas, and each dimensional indicator based on the sample calculation, respectively. The average value of the same industry in the identical period of the dimensional indicators is deducted, and the results are divided by the standard deviation of the same industry in the same period of the indicator, and standardized to take the absolute value $D S_{i, t}$, as shown in Equation (1). The larger the indicator is, the greater the difference between the strategy deviation of the company and its industry peers, and the higher the business risk it faces because it is out of the norm.

Figure 2 presents the mean and trend of corporate strategy deviation for each year. Broadly speaking, it seems that the data has undergone a process from high to low, with a rebound oscillation higher. The smallest year is 2008 , which is probably due to the fact that the listed 
Table 1. Classification and measurement of strategy deviation of enterprises

\begin{tabular}{|c|c|c|c|c|c|}
\hline $\begin{array}{l}\text { Three } \\
\text { domains }\end{array}$ & $\begin{array}{c}\text { Six } \\
\text { dimensions } \\
(\mathrm{N}=6)\end{array}$ & Specific measurement formula & Mean1 & $\begin{array}{l}\text { Sample industry } \\
\text { level }\end{array}$ & Mean2 \\
\hline \multirow[t]{3}{*}{$\begin{array}{l}\text { Production } \\
\text { and R\&D }\end{array}$} & $\begin{array}{l}\text { Capital } \\
\text { intensity }\end{array}$ & $\begin{array}{l}\text { Dimension }_{1, i, t}=\text { Net fixed } \\
\text { assets/number of } \\
\text { employees }\end{array}$ & 752196.4 & \multirow{6}{*}{$\begin{array}{l}\text { Industry mean: } \\
M E A N_{n, i, t} \\
\text { Industry standard } \\
\text { deviation: } \\
S D_{n, i, t} \\
n=\{1,2,3,4,5,6\}\end{array}$} & 0.5789 \\
\hline & $\begin{array}{l}\text { Degree of } \\
\text { renewal of } \\
\text { fixed assets }\end{array}$ & $\begin{array}{l}\text { Dimension }_{2, i, t}=\text { Net fixed } \\
\text { assets/original value }\end{array}$ & 0.5995 & & 0.7966 \\
\hline & $\begin{array}{l}\text { R\&D } \\
\text { investment }\end{array}$ & $\begin{array}{l}\text { Dimension }_{3, i, t}=\text { Net intangible } \\
\text { assets/operating revenue }\end{array}$ & 0.2698 & & 0.5416 \\
\hline \multirow[t]{2}{*}{$\begin{array}{l}\text { Marketing } \\
\text { and input }\end{array}$} & $\begin{array}{l}\text { Advertising } \\
\text { and } \\
\text { promotion } \\
\text { input }\end{array}$ & $\begin{array}{l}\text { Dimension }_{4, i, t}=\text { Sales expense/ } \\
\text { operatingrevenue }\end{array}$ & 0.0611 & & 0.7158 \\
\hline & $\begin{array}{l}\text { Management } \\
\text { expenses }\end{array}$ & $\begin{array}{l}\text { Dimension }_{5, i, t}=\text { management } \\
\text { expenses/operating income }\end{array}$ & 0.0868 & & 0.6707 \\
\hline $\begin{array}{l}\text { Finance } \\
\text { and } \\
\text { financing }\end{array}$ & $\begin{array}{l}\text { Financial } \\
\text { leverage }\end{array}$ & $\begin{array}{l}\text { Dimension }_{6, i, t}=(\text { short-term } \\
\text { borrowing + long-term } \\
\text { borrowing + bonds payable }) / \\
\text { total owner's equity }\end{array}$ & 0.5772 & & 0.7572 \\
\hline $\begin{array}{l}\text { Corporate } \\
\text { strategy } \\
\text { deviation }\end{array}$ & \multicolumn{4}{|l|}{$D S_{i, t}=\{$} & (1) \\
\hline
\end{tabular}

Note: Mean1 is the sample mean of Dimensionn $n_{i, t}$ and Mean2 is the sample mean of |(Dimen$\left.\operatorname{sionn}_{i, t}-M E A N_{n, i, t}\right) / S D_{n, i, t} \mid$ (each of the six strategic dimension indicators minus the mean of the indicator in the same industry, divided by the standard deviation of the indicator to standardize and take the absolute value). There are few separately disclosed data on advertising expenses and R\&D expenses for listed companies in China, therefore, in this paper, cost of sales and net intangible assets are used to obtain the approximate values instead of the advertising expenses and $\mathrm{R} \& \mathrm{D}$ expenses, respectively. In the stability test, we remove these two parts of these approximate values, and carry out the reorganization and regression, in this manner to maintain the consistency of the results.

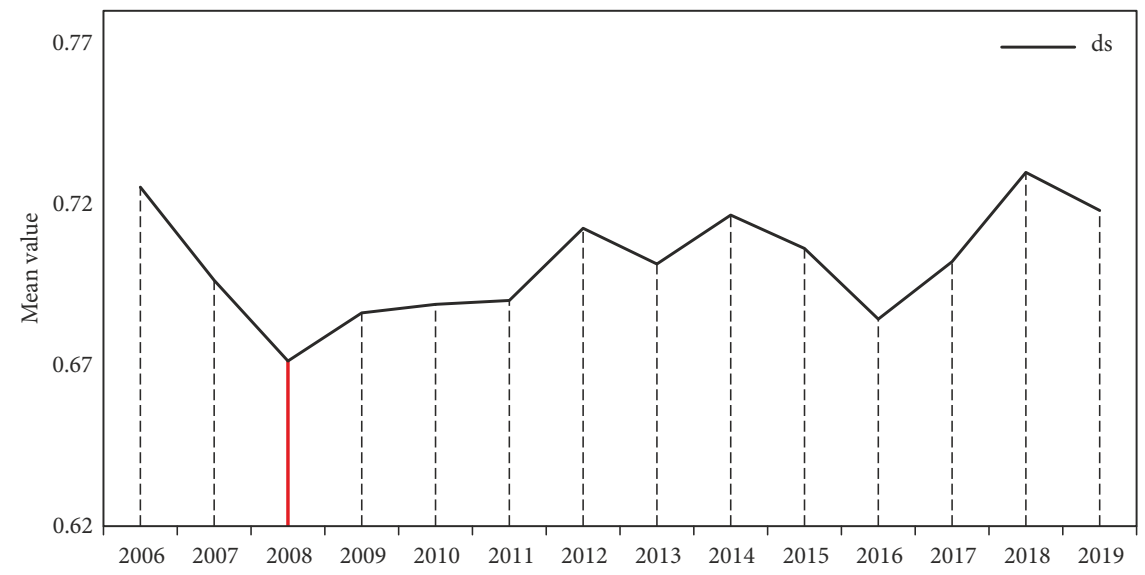

Figure 2. Annual trend of the mean value of corporate strategy deviation 
companies were more cautious in their strategic layout under the influence of the financial crisis and adopted more conventional and empirical strategic decisions to reduce their business risks and avoid the negative impacts of the harsh economic environment.

Figure 3 presents the mean values of strategic deviations for different industries in the first and last year of the time series (only first quarter data are available for 2020). The Scientific Research and Technology Services industry is the one with the highest mean value, indicating that innovative development is more important for this industry. The real estate sector, meanwhile, has a mean value of 0.56 for the full sample, with listed companies in this sector being at the "windfall" of China's rapid growth over the last twelve years. Many non-real estate companies are even involved in the real estate business, so it is a relatively small industry deviation overall, and most companies are using more conventional strategies, and already have a good performance. The results obtained by using the above method to measure the strategic deviation of enterprises are in line with the reality of China's economic and social development.

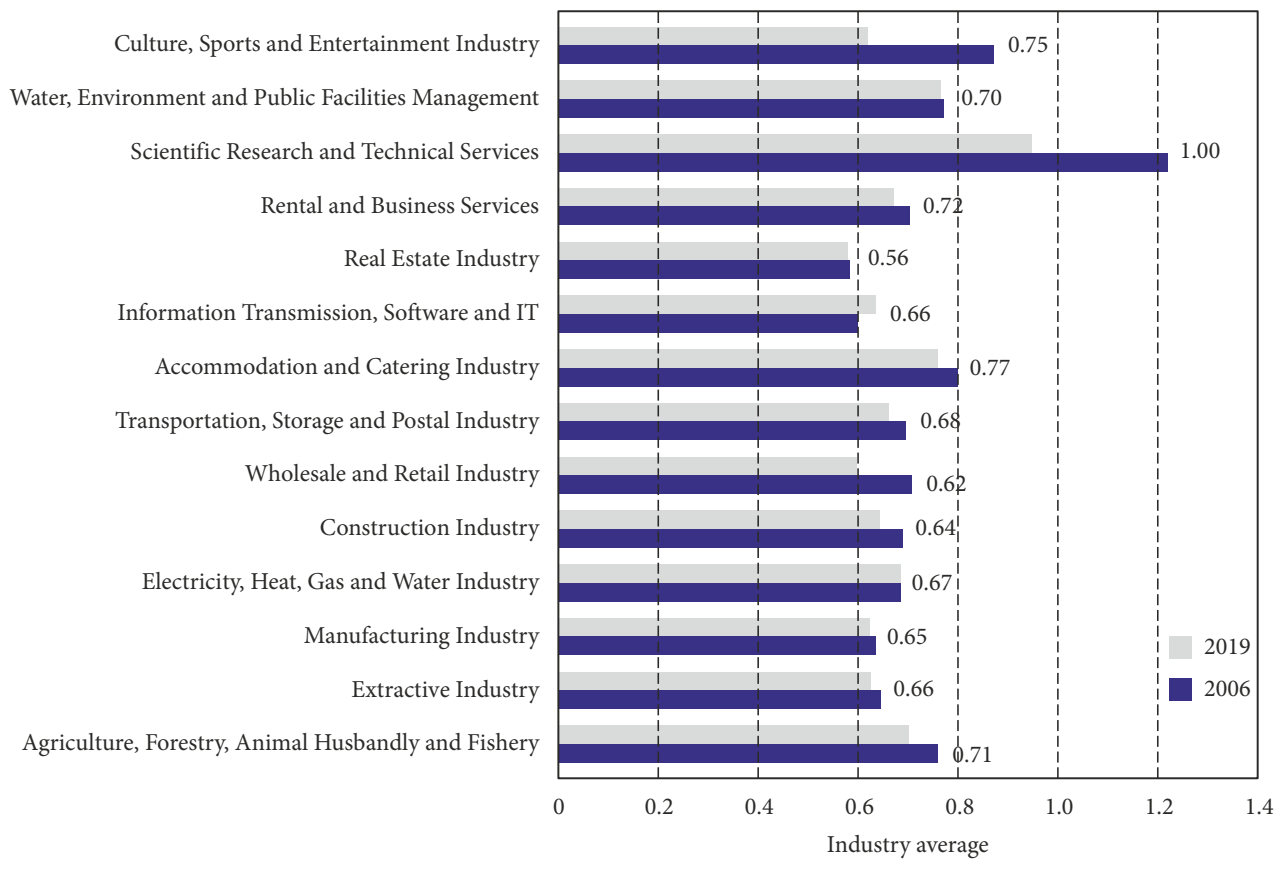

Note: The dark blue bar shows the mean value of corporate strategy deviation for each industry in 2006, and the grey shows the mean value of corporate strategy deviation for each industry in 2019. The red markers are the mean values of corporate strategy deviation for each industry for the full sample. The industry classification standard is the Industry Classification Guidelines for Listed Companies issued by the China Securities Regulatory Commission in 2012.

Figure 3. Mean value of corporate strategy deviation by industry 


\subsection{Measurement of institutional investors' approval}

Using network topology to study microstructure in financial markets and express structural problems (Chen et al., 2017). The use of data mining and analysis methods to study socioeconomic issues has dominated various research areas ( $\mathrm{Li} \& \mathrm{Liu}, 2020$ ). In most cases, the shareholding ratio is used as an indicator of the recognition in the traditional studies of institutional investors, and the most direct manifestation of institutional recognition is to increase their holdings, while that of disapproval is to reduce their holdings. In this process, it would be more accurate to consider the micro-holding network among the whole market, that is to say, if the whole capital market is considered as a network, and a listed company's stock is recognized by the market, the "edge" generated therein will be more intensive or thought as a "point", and the point is in a more important position in the network. Analyzed from the perspective of multidimensional data, building topologies can better reflect the relationships in the stock market (Yin et al., 2020). In this paper, the degree of recognition of institutional investors is measured, and a complex network of fund networks is created according to the research idea of Pareek (2012) to study the relationship between shareholding grouping and stock market shocks. Following steps are followed in this paper to measure the recognition of institutional investors.

\section{Generally accepted by institutional investors of listed companies}

In this paper, the financial complex network is defined as follows: when an institution holds more than $1 \%$ of the outstanding shares of the enterprise's stock, it is deemed as a long position. When two institutions have a long position in the same enterprise at the same time, they constitute the edge Link $I$ (long position is the only condition to constitute the matrix), and the holding institution constitutes Point $J$. After traversing the data at a frequency of 2 , the complex network is constituted, which is recorded as $N\left(d_{i j}\right)$.

By collation and extraction, the explanatory Variable $I$ is constituted, i.e., firm i's institutional generally accepted weight formula.

$$
\text { Groupown }_{i, t}=\sum_{j}^{n} \gamma_{i, j, t} X_{i, j},
$$

where, $\gamma_{i, j, t}$ in Equation (2) represents the proportion of relevant institutional holdings in the complex network. In this manner, this data portrays the market prevalence of institutional investors' recognition. The larger the Groupown $n_{i, t}$, the more optimistic the majority of institutional investors in the capital market, and the higher the level of recognition.

\section{Clustering (grouping) recognition of institutional investors in listed companies}

For complex networks $N\left(d_{i j}\right)$, the GN algorithm proposed by the study of Newman and Girvan (2004) is used for the performance of clustering, which has become a classical algorithm in complex network structure analysis in recent years. The basic idea is to regard the network $N\left(d_{i j}\right)$ as a traffic network with two community groups $A$ and $B$. And the link $I(a, b)$ between them will show high traffic flow, finding all $I(a, b)$ and removing, where, $I(a, b)$ is called bottleneck measured by the mediator degree of the edge. The classification and clustering of complex networks can be completed by calculating the intermediate degree of all edges, and removing the edge with the maximum intermediate degree to form groups. And then, the 
calculation is repeated until the bottleneck disappears, and the calculation ends when the result is stable. This algorithm is a split hierarchical clustering algorithm, and the calculation principle and example are shown in Figure 4.

In this paper, the GN algorithm is used to calculate and obtain the aggregated group measures formed by the institutions in the process of increasing their holdings in the enterprises by collating and extracting the largest class in size, which constitutes the explanatory variable $I$, i.e., the institutional clustering of enterprise $i$. recognized weight formula, as expressed below:

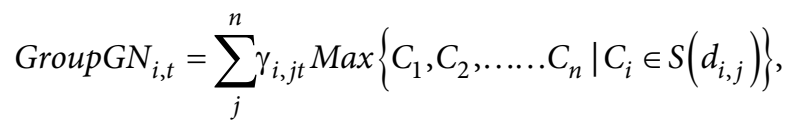

where, $C_{i}$ in Equation (3) refers to the largest institutional group after GN clustering, and the larger Group $G N_{i, t}$, the more concentrated and grouped the institutional investors in the capital market response, and the higher the degree of recognition.

\subsection{Empirical model, sample selection and data sources}

Some firms are motivated to make a new strategic decision only when they fail to compete in the current market, or when the market demand for the firm's products declines, thus making the firm's strategy deviation biased. In addition, this type of firm itself may find it difficult to gain the recognition of external investors. To avoid this endogeneity, seven control variables related to the firm itself and the external capital market are selected in this paper, which present the nature of firm ownership, that is $S_{0} e_{i, t}$; which refers to the average excess turnover rate $D_{t u r n}, ;$, which represents the market net ratio $M t b_{i, t}$; which denotes the individual stock specific return $\operatorname{Ret}_{i, t}$; which refers to the standard deviation of weekly returns $\operatorname{Sigma}_{i, t}$; which present the natural logarithm of total assets $\operatorname{Size}_{i, t}$; and asset liability ratio $\operatorname{lev}_{i, t}$, which refers to a two-way fixed effects regression model.

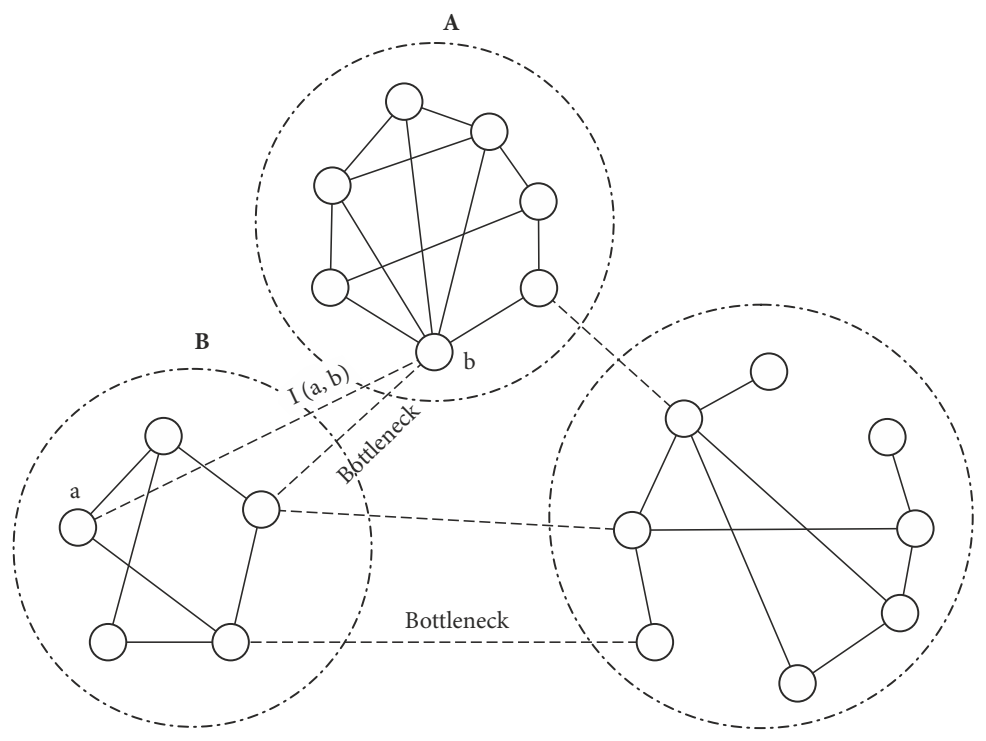

Figure 4. Example of GN algorithm 
The Equations of (4) and (5) are used in this paper to demonstrate the relationship between the strategy deviations of listed firms and the recognition of institutional investors, expressed as follows:

$$
\begin{aligned}
& \text { Groupown }_{i, t}=\alpha_{1}+\beta_{1} D S_{i, t}+\beta_{2} \text { Soe }_{i, t}+\beta_{3} \text { Dturn }_{i, t}+\beta_{4} M t b_{i, t}+\beta_{5} \text { Ret }_{i, t}+ \\
& \beta_{6} \text { Sigma }_{i, t}+\beta_{7} \text { Size }_{i, t}+\beta_{8} \text { Lev }_{i, t}+\varepsilon_{i, t} \\
& \text { GroupGN }_{i, t}=\alpha_{1}+\beta_{1} D S_{i, t}+\beta_{2} \text { Soe }_{i, t}+\beta_{3} \text { Dturn }_{i, t}+\beta_{4} \text { Mtb }_{i, t}+\beta_{5} \text { Ret }_{i, t}+ \\
& \beta_{6} \text { Sigma }_{i, t}+\beta_{7} \text { Size }_{i, t}+\beta_{8} \text { Lev }_{i, t}+\varepsilon_{i, t}
\end{aligned}
$$

where, Groupown $n_{i, t}$ refers to the general institutional approval of firm $i$, and GroupGN ${ }_{i, t}$ represents the institutional clustering approval of firm $i$. Both of them measure the approval degree of institutional investors on firm's strategy deviation from different perspectives. $D S_{i, t}$ denotes the strategy deviation of firm $i$, and $\varepsilon_{i, t}$ is the error term.

Sample selection and data sources. In view of the large differences in China's corporate accounting system and auditing standards after 2006, this paper selects a total of 57 issues of consolidated A-shares from 2006 to the first quarter of 2020 as the sample. In addition, Cathay Capital (CSMAR) ${ }^{2}$ series research database and fund reports ${ }^{3}$ of fund companies are used as the financial data sources, and the existing research is taken as the reference for the following processing:

- First: Exclude large financial enterprises for decentring;

- Second: Delete the ST category enterprises and retains normally traded enterprises;

- Third: Exclude stocks with trading weeks less than 30 from the annual data;

- Four: Remove individuals with missing values from the calculation of Groupown $n_{i, t}$, GroupGN $N_{i, t}$ and $D S_{i, t}$. And finally, we obtain 56,264 quarterly samples with a total of 952 listed companies;

- Five: In order to avoid the influence of outliers, all continuous variables are Winsorized at the levels of $1 \%$ and $99 \%$ in the empirical test in this paper. And the descriptive statistics of each variable are shown in Table 2.

\section{Results and discussion}

\subsection{Data smoothness, multicollinearity and correlation test}

Due to the fact that modern time series theory is also applied to panel data, this paper aims to avoid the phenomenon of pseudo-regression on the 57-period long panel for the stability test, and ADF unit root test, as shown in Table 4. It can be seen from the table that the variables lagged first order strongly reject the original hypothesis of the existence of unit root in the panel data, and the variables show stationarity. Meanwhile, in order to avoid multicollinearity, this paper calculates and reports the VIF values of each variable, as shown in Table 3. The average value of VIF is less than 2 , and the maximum value is 1.44 , which is far below the critical value of 10 , indicating, to some extent, that there is no multicollinearity between the variables.

\footnotetext{
${ }^{2}$ China Stock Market \& Accounting Research Database is a research-oriented and accurate database in the field of economy and finance developed by Shenzhen Sigma Data Technology Co., Ltd. from the needs of academic research and combining with the actual situation of China.

3 Asset Management Association of China publishes data relating to fund reporting on a regular basis (http://amac. org.cn).
} 
Table 2. Calculation of variables and basic statistical descriptions

\begin{tabular}{|l|l|c|c|c|c|c|}
\hline \multicolumn{1}{|c|}{ Variable } & \multicolumn{1}{|c|}{ Variable label } & Min & Max & Mean & Std.Dev & Obs \\
\hline Groupown $_{i, t}$ & $\begin{array}{l}\text { Institutional Investor Approval, Holding } \\
\text { Size Factor }\end{array}$ & 0.0000 & 0.1350 & 0.0139 & 0.0284 & 54264 \\
\hline${\text { Group } G N_{i, t}}$ & $\begin{array}{l}\text { Institutional Investor Approval, } \\
\text { Shareholding Clustering Factor }\end{array}$ & 0.0000 & 0.2426 & 0.0047 & 0.0240 & 54264 \\
\hline$S_{i, t}$ & $\begin{array}{l}\text { Strategic differentiation of listed } \\
\text { enterprises, i.e., the extent to which } \\
\text { the strategy deviates from the industry } \\
\text { average }\end{array}$ & 0.0000 & 1.0000 & 0.6754 & 0.4682 & 54264 \\
\hline Soe $_{i, t}$ & $\begin{array}{l}\text { Nature of ownership, with controlling } \\
\text { shareholders being state-owned } \\
\text { enterprises taking a value of } 1 \text { and } \\
\text { others taking a value of } 0\end{array}$ & 0.0000 & 1.0000 & 0.6754 & 0.4682 & 54264 \\
\hline Dturn $_{i, t}$ & $\begin{array}{l}\text { Average excess turnover, average of } \\
\text { current months turnover }- \text { average of } \\
\text { previous month's turnover }\end{array}$ & -1.3078 & 1.2788 & -0.0014 & 0.3315 & 54264 \\
\hline Mtb $_{i, t}$ & $\begin{array}{l}\text { Market Net Ratio. Current balance sheet } \\
\text { date closing price / (current owner's } \\
\text { equity / current paid-in capital) }\end{array}$ & 0.0054 & 0.1401 & 0.0300 & 0.0198 & 54264 \\
\hline Ret $_{i, t}$ & $\begin{array}{l}\text { Individual stock-specific returns, } \\
\text { average of weekly returns } W_{i, t} \text { by } \\
\text { industry in year } t w_{i}\end{array}$ & -0.0129 & 0.0247 & 0.0010 & 0.0043 & 54264 \\
\hline Sigma $_{i, t}$ & $\begin{array}{l}\text { Standard deviation of weekly returns, } \\
\text { standard deviation of corporate earnings } \\
\text { by industry and year } \sqrt{\sum}\left(w_{i, t}-w_{i}\right) / N\end{array}$ & 0.0088 & 0.0811 & 0.0289 & 0.0114 & 54264 \\
\hline Lev $_{i, t}$ & $\begin{array}{l}\text { Natural logarithm of total assets } \\
\text { Gearing ratio }\end{array}$ & 8.6226 & 10.7815 & 9.6215 & 0.4947 & 54264 \\
\hline
\end{tabular}

Table 3. VIF values of variables

\begin{tabular}{|l|c|c|}
\hline \multicolumn{3}{|c|}{ Explained variable: Groupown } \\
$i, t$ \\
\hline Size $_{i, t}$ GroupGN $_{i, t}$ \\
\hline Mtb $_{i, t}$ & 1.4400 & 0.6930 \\
\hline Sigma $_{i, t}$ & 1.3400 & 0.7482 \\
\hline Lev $_{i, t}$ & 1.1900 & 0.8381 \\
\hline Ret $_{i, t}$ & 1.1800 & 0.8453 \\
\hline Dturn $_{i, t}$ & 1.1100 & 0.8990 \\
\hline GroupGN $_{i, t}$ & 1.0700 & 0.9358 \\
\hline Soe $_{i}$ & 1.0400 & 0.9602 \\
\hline SS $_{i, t}$ & 1.0400 & 0.9633 \\
\hline Mean VIF & 1.0100 & 0.9911 \\
\hline
\end{tabular}


The Pearson correlation between listed firms' strategy deviation and institutional investors' approval is shown in Table 5. The correlation among $D S_{i, t}$, Groupown $i, t$ and GroupGN $N_{i, t}$ are negative, i.e., -0.0219 and -0.0148 , respectively. There is a negative effect between strategic deviation of listed companies and institutional investors' recognition without considering other conditions, i.e., non-recognition, which is also consistent with the result of the basic recognition analysis mentioned in the previous section. And the test tentatively verifies Hypothesis 1 .

Table 4. ADF unit root test results for the variables

\begin{tabular}{|l|c|c|c|c|c|}
\hline \multicolumn{1}{|c|}{ Variable } & Groupown $_{i, t}$ & GroupGN $_{i, t}$ & DS $_{i, t}$ & Soe $_{i}$ & Dturn $_{i, t}$ \\
\hline Lag.1 & $0.9646^{* * *}$ & $-18.9953^{* * *}$ & $-51.1255^{* * *}$ & ----- & $-1.7 \mathrm{e}+02^{* * *}$ \\
\hline variable & $M t b_{i, t}$ & Ret $_{i, t}$ & Sigma $_{i, t}$ & Size $_{i, t}$ & Lev $_{i, t}$ \\
\hline Lag.1 & $-38.0468^{* * *}$ & $-94.7971^{* * *}$ & $-49.8170^{* * *}$ & $-34.9373^{* * *}$ & $-21.2247^{* * *}$ \\
\hline
\end{tabular}

Note: Tables report $t$-values. ${ }^{*}{ }^{* *},{ }^{* *}$ indicate the significance at the statistical levels of $10 \%, 5 \%$, and $1 \%$, respectively.

Table 5. Pearson correlation coefficients of the variables

\begin{tabular}{|l|c|c|c|c|c|c|c|c|c|c|}
\hline \multicolumn{1}{|c|}{ Variable } & Groupown $_{i, t}$ & GroupGN $_{i, t}$ & $D_{i, t}$ & Soe $_{i}$ & Dturn $_{i, t}$ & Mtb $_{i, t}$ & Ret $_{i, t}$ & Sigma $_{i, t}$ & Size $_{i, t}$ & Lev $_{i, t}$ \\
\hline Groupown $_{i, t}$ & 1.0000 & & & & & & & & \\
\hline GroupGN $_{i, t}$ & $0.0862^{* * *}$ & 1.0000 & & & & & & & \\
\hline DS $_{i, t}$ & $-0.0219^{* * *}$ & $-0.0148^{* * *}$ & 1.0000 & & & & & & & \\
\hline Soe $_{i, t}$ & $-0.1064^{* * *}$ & $-0.0071^{*}$ & -0.0017 & 1.0000 & & & & & & \\
\hline Dturn $_{i, t}$ & $-0.0183^{* * *}$ & $-0.0214^{* * *}$ & $0.0251^{* * *}$ & -0.0043 & 1.0000 & & & & & \\
\hline Mtb $_{i, t}$ & $0.1036^{* * *}$ & $0.1501^{* * *}$ & $0.0751^{* * *}$ & $-0.1202^{* * *}$ & $-0.0301^{* * *}$ & 1.0000 & & & & \\
\hline Ret $_{i, t}$ & 0.0028 & $0.1161^{* * *}$ & $0.0176^{* * *}$ & $-0.0130^{* * *}$ & $0.1645^{* * *}$ & $0.2432^{* * *}$ & 1.0000 & & & \\
\hline Sigma $_{i, t}$ & $-0.0177^{* * *}$ & $0.1229^{* * *}$ & $0.0072^{*}$ & $-0.0298^{* * *}$ & $0.1711^{* * *}$ & $0.2874^{* * *}$ & $0.1720^{* * *}$ & 1.0000 & & \\
\hline Size $_{i, t}$ & $0.0150^{* * *}$ & $-0.0296^{* * *}$ & 0.0048 & $0.1734^{* * *}$ & $-0.0182^{* * *}$ & $-0.3969^{* * *}$ & $-0.1105^{* * *}$ & $-0.2598^{* * *}$ & 1.0000 & \\
\hline Lev $_{i, t}$ & $-0.0379^{* * *}$ & -0.0010 & $0.0150^{* * *}$ & $0.1092^{* * *}$ & -0.0014 & $-0.1068^{* * *}$ & -0.0041 & $0.0120^{* * *}$ & $0.3726^{* * *}$ & 1.0000 \\
\hline
\end{tabular}

\subsection{Baseline model regression}

Table 6 shows the regression results of strategy deviation of the listed firms and institutional investor recognition. Where, (1) and (2) show the random effects of the panel model excluding the control variables; (3) and (4) show the random effects of the panel including the control variables, besides, (5) and (6) are presented as two-way fixed effects regressions for panel data with the inclusion of control variables, thereby controlling the potential heteroskedasticity and correlation. The standard errors of all regression coefficients are cluster-treated at the individual level, and the results of the above regressions are all stable negative effects, the model is used for regressions throughout the following sections.

Specifically, the relationship between the strategy deviation of listed companies and the general approval of institutional investors is negative at the statistical level of $10 \%$, when the coefficient of the explanatory variable $D S_{i, t}$ is $-0.34 \%$; while the relationship with the approval of institutional investors' clustering is negative at the statistical level of $1 \%$, when the 
Table 6. Corporate strategy deviation and institutional investor recognition

\begin{tabular}{|c|c|c|c|c|c|c|}
\hline \multirow{2}{*}{ Variables } & Groupown $_{i, t}$ & Group $N_{i, t}$ & Groupown $_{i, t}$ & Group $G N_{i, t}$ & Groupown $_{i, t}$ & Group $G N_{i, t}$ \\
\hline & (1) & (2) & (3) & (4) & (5) & (6) \\
\hline$D S_{i, t}$ & $\begin{array}{c}-0.0024^{* * *} \\
(-5.0924)\end{array}$ & $\begin{array}{c}-0.0014^{* * *} \\
(-3.4544)\end{array}$ & $\begin{array}{c}-0.0034^{\star * *} \\
(-7.4549)\end{array}$ & $\begin{array}{c}-0.0023^{* * *} \\
(-5.9899)\end{array}$ & $\begin{array}{l}-0.0034^{\star} \\
(-1.9545)\end{array}$ & $\begin{array}{c}-0.0020^{* * *} \\
(-3.0433)\end{array}$ \\
\hline $\mathrm{Soe}_{i}$ & & & $\begin{array}{l}-0.0062^{* * *} \\
(-23.7252)\end{array}$ & $\begin{array}{c}0.0001 \\
(0.6561)\end{array}$ & $\begin{array}{c}-0.0060^{* * *} \\
(-4.3130)\end{array}$ & $\begin{array}{c}-0.0004 \\
(-0.9118)\end{array}$ \\
\hline Dturn $_{i, t}$ & & & $\begin{array}{c}-0.0004 \\
(-0.9484)\end{array}$ & $\begin{array}{l}-0.0033^{* * *} \\
(-10.6286)\end{array}$ & $\begin{array}{l}-0.0006^{\star *} \\
(-2.1581)\end{array}$ & $\begin{array}{c}-0.0017^{* * *} \\
(-5.3487)\end{array}$ \\
\hline$M t b_{i, t}$ & & & $\begin{array}{l}0.1999^{* * *} \\
(28.6728)\end{array}$ & $\begin{array}{l}0.1509^{\star * *} \\
(25.7441)\end{array}$ & $\begin{array}{c}0.2145^{* * *} \\
(6.4008)\end{array}$ & $\begin{array}{l}0.1672^{\star * *} \\
(10.8340)\end{array}$ \\
\hline $\operatorname{Ret}_{i, t}$ & & & $\begin{array}{c}-0.1018^{\star * *} \\
(-3.4293)\end{array}$ & $\begin{array}{l}0.4721^{\star * *} \\
(18.9175)\end{array}$ & $\begin{array}{c}-0.0153 \\
(-0.5455)\end{array}$ & $\begin{array}{c}0.2031^{* * *} \\
(6.5872)\end{array}$ \\
\hline $\operatorname{Sigma}_{i, t}$ & & & $\begin{array}{c}-0.0791^{\star * *} \\
(-6.9125)\end{array}$ & $\begin{array}{l}0.2011^{\star * *} \\
(20.8984)\end{array}$ & $\begin{array}{l}-0.0487^{\star} \\
(-1.7041)\end{array}$ & $\begin{array}{c}0.0118 \\
(0.8843)\end{array}$ \\
\hline $\operatorname{Size}_{i, t}$ & & & $\begin{array}{l}0.0055^{\star * *} \\
(18.8039)\end{array}$ & $\begin{array}{l}0.0027^{\star * *} \\
(11.1367)\end{array}$ & $\begin{array}{c}0.0044^{\star * *} \\
(3.2001)\end{array}$ & $\begin{array}{l}0.0056^{* * *} \\
(11.2453)\end{array}$ \\
\hline$L e v_{i, t}$ & & & $\begin{array}{l}-0.0074^{* * *} \\
(-10.1582)\end{array}$ & $\begin{array}{l}-0.0013^{* *} \\
(-2.0687)\end{array}$ & $\begin{array}{l}-0.0057^{\star} \\
(-1.7251)\end{array}$ & $\begin{array}{c}-0.0030^{* * *} \\
(-2.7885)\end{array}$ \\
\hline Constant & $\begin{array}{l}0.0155^{\star * *} \\
(47.0818)\end{array}$ & $\begin{array}{l}0.0056^{\star * *} \\
(20.2939)\end{array}$ & $\begin{array}{l}-0.0322^{\star * *} \\
(-11.3914)\end{array}$ & $\begin{array}{l}-0.0302^{* * *} \\
(-12.7094)\end{array}$ & $\begin{array}{l}-0.0241^{\star} \\
(-1.8697)\end{array}$ & $\begin{array}{l}-0.0512^{* * *} \\
(-10.5646)\end{array}$ \\
\hline Ctrl/Clu/YR & $\mathrm{N} / \mathrm{N} / \mathrm{Y}$ & $\mathrm{N} / \mathrm{N} / \mathrm{Y}$ & $\mathrm{Y} / \mathrm{N} / \mathrm{Y}$ & $\mathrm{Y} / \mathrm{N} / \mathrm{Y}$ & $\mathrm{Y} / \mathrm{Y} / \mathrm{Y}$ & $\mathrm{Y} / \mathrm{Y} / \mathrm{Y}$ \\
\hline $\mathrm{N}$ & 54,262 & 54,262 & 54,262 & 54,262 & 54,262 & 54,262 \\
\hline Adi. $R^{2}$ & 0.0005 & 0.0002 & 0.0296 & 0.0397 & 0.0448 & 0.1202 \\
\hline
\end{tabular}

Note: ${ }^{*},{ }^{*},{ }^{* * *}$ indicate the significance at the $10 \%, 5 \%$, and $1 \%$ statistical levels, respectively. While, the letters of $\mathrm{N}$ and $\mathrm{Y}$ indicate whether the control variables, years and documented standard errors are uncontrolled or controlled. The $t$-values are in parentheses, same as below.

coefficient of the explanatory variable $D S_{i, t}$ is $-0.20 \%$. The regression results indicate that the greater the difference in strategy deviation of listed companies, the lower the institutional investors' approval of the decision to hold outstanding shares of that company, and Hypothesis 1 is verified. Among them, the institutional clustering recognition in the capital market from the calculation process often refers to the grouped institutions or head institutions in the capital market, which is relatively low in information asymmetry, and more sensitive to corporate strategy, showing a more significant effect result. Compared with the results of general recognition of institutional investors, the coefficients are slightly different, and the possibility of adverse selection is low, which can better characterize and distinguish the deviation of differences in corporate strategy deviation. Therefore, the decision is available to reduce holdings, or makes the exit more rational. Hypothesis 1 is tested. 


\subsection{Further research}

\section{Asymmetry of institutional investors' recognition in six dimensions of three major areas of corporate strategy deviation differences}

In the previous paper, when measuring corporate strategy deviation, the corporate strategy is divided into three key areas in this paper, such as production and $\mathrm{R} \& \mathrm{D}$, marketing and input, and finance and financing, which are further divided into six dimensions to jointly the measure corporate strategy deviation, and grouped in order to observe the relationship between corporate strategy and institutional investors' recognition on a more detailed basis. The six dimensions in $D S_{i, t}$ for each firm were ranked according to the weights conducted and grouped with the highest weights. Based on Figure 1, all samples were finally divided into strategy deviation dominated by production and $\mathrm{R} \& \mathrm{D}$ areas, strategy deviation dominated by marketing and inputs, and strategy deviation dominated by finance and financing. Due to the fact that the data is a long panel, the regression is an unbalanced panel regression, in the meantime, firms may undergo style shifts in strategy deviation over a longer operating period, but it has no impact on our ability to observe the relationship between the three groupings and institutional investor recognition.

As shown in Table 7, the regressions of strategy deviation of listed companies are grouped by six dimensions in three major areas to examine the relationship with institutional investor recognition. Among them, the models of (1) and (2) refer to the strategy deviation dominated by the production and R\&D area, which shows that investment institutions are generally very sensitive to the emergence of industry strategic differences among companies in terms of capital investment and expansion of production capacity. Too high or too low investment may make institutional investors less optimistic about the future cash inflows of assets due to the risk issues, and the clustered institutional groups also show a negative endorsement, i.e., a magnitude reduction in holdings with lower relative general recognition. The models of (3) and (4) refer to the marketing and input-led strategy deviation, and the investment institutions are generally more insensitive to the emergence of strategic differences in the external

Table 7. Asymmetries in the six dimensions of the three major areas of corporate strategy deviation

\begin{tabular}{|l|c|c|c|c|c|c|}
\hline \multirow{3}{*}{ Variables } & \multicolumn{2}{|c|}{ Production and R\&D } & \multicolumn{2}{c|}{ Marketing and input } & \multicolumn{2}{c|}{ Finance and financing } \\
\cline { 2 - 7 } & Groupown $_{i, t}$ & GroupGN $_{i, t}$ & Groupown $_{i, t}$ & GroupGN $_{i, t}$ & Groupown $_{i, t}$ & ${\text { Group } G N_{i, t}}$ \\
\cline { 2 - 7 } & $(1)$ & $(2)$ & $(3)$ & $(4)$ & $(5)$ & $(6)$ \\
\hline$D_{i, t}$ & $-0.0055^{* * *}$ & $-0.0015^{*}$ & 0.0028 & $-0.0018^{*}$ & -0.0020 & -0.0024 \\
& $(-2.8382)$ & $(-1.7913)$ & $(0.9324)$ & $(-1.7675)$ & $(-0.5833)$ & $(-1.5187)$ \\
\hline Soe $_{i}$ & $-0.0075^{* * *}$ & -0.0001 & $-0.0058^{* * *}$ & -0.0004 & -0.0030 & -0.0010 \\
& $(-4.5259)$ & $(-0.1414)$ & $(-3.0419)$ & $(-0.6850)$ & $(-1.4927)$ & $(-1.1432)$ \\
\hline Constant & -0.0169 & $-0.0446^{* * *}$ & $-0.0441^{* *}$ & $-0.0559^{* * *}$ & -0.0236 & $-0.0585^{* * *}$ \\
& $(-1.1766)$ & $(-7.5639)$ & $(-2.1462)$ & $(-7.4621)$ & $(-1.1515)$ & $(-6.1907)$ \\
\hline Controls & $\mathrm{Y}$ & $\mathrm{Y}$ & $\mathrm{Y}$ & $\mathrm{Y}$ & $\mathrm{Y}$ & $\mathrm{Y}$ \\
\hline $\mathrm{N}$ & 24,414 & 24,414 & 17,463 & 17,463 & 12,385 & 12,385 \\
\hline Adi. $\mathrm{R}^{2}$ & 0.0560 & 0.1210 & 0.0390 & 0.1250 & 0.0510 & 0.1170 \\
\hline
\end{tabular}


publicity and expenses of the company. While, the clustered institutional groups result in a reduction in their holdings, as can be seen from the perspective of this paper, the institutional endorsement bias is different, with most institutional investors being more concerned with balance sheet matters, and the clustered institutional groups are more concerned with income statement matters. The models of (5) and (6) refer to the finance and financing oriented strategic bias that is insensitive to corporate financial leverage. It is likely that the capital assets gained (reduced) by the changes in corporate debt policy are ultimately reflected by expanding (shrinking) investments or increasing (reducing) cost expenditures. Their gearing ratios not exceeding the alarming levels are considered as safe by institutional investors, and not strategically risky. In summary, corporate strategic deviation is recognized by institutional investors asymmetrically in different areas and dimensions. Hypothesis 2 is tested.

\section{Asymmetry test of institutional investors' recognition} of listed enterprises with different property rights nature

The previous benchmark regressions focused on the nature of property rights as a control variable, and in this paper, the regression results were grouped according to the nature of property rights and shareholders' background of listed enterprises, with state-owned enterprises as a group and non-state-owned enterprises and others as the other group, as shown in Table 8.

As shown in Table 8, the models of (1) and (2) refer to the state-owned enterprises in the nature of ownership, while the models of (3) and (4) refer to the non-state-owned enterprises in the nature of ownership. When the listed SOEs known for having robust and smooth corporate decisions show a large deviation in their strategy deviation, and takes their business style contrary to the industry mean, the institutional investors in the market generally will not accept the strategic style. Besides, both the overall network and the clustering network show significant negative recognition. However, for private and foreign firms, when a deviation in strategy deviation exists, and the business style is against the industry mean, the institutional investors in the market will not be sensitive to this, and the negative endorsement is not significant for either the overall network or the clustering network. Therefore, Hypothesis 3 proposed as: institutional investors' recognition of listed enterprises with different property rights nature shows asymmetry, is verified.

Table 8. Asymmetries in corporate strategy deviation and institutional investor recognition - regression of property rights grouping

\begin{tabular}{|l|c|c|c|c|}
\hline \multirow{3}{*}{ Variables } & Groupown $_{i, t}$ & GroupGN $_{i, t}$ & Groupown $_{i, t}$ & GroupGN $_{i, t}$ \\
\cline { 2 - 5 } & $(1)$ & $(2)$ & $(3)$ & $(4)$ \\
\hline${ }^{*} S_{i, t}$ & $-0.0039^{* *}$ & $-0.0024^{* * *}$ & -0.0037 & -0.0013 \\
& $(-2.0723)$ & $(-3.1380)$ & $(-1.0227)$ & $(-1.1143)$ \\
\hline Constant & -0.0249 & $-0.0543^{* * *}$ & -0.0311 & $-0.0505^{* * *}$ \\
& $(-1.5998)$ & $(-9.3413)$ & $(-1.2157)$ & $(-5.5835)$ \\
\hline Controls & $\mathrm{Y}$ & $\mathrm{Y}$ & $\mathrm{Y}$ & $\mathrm{Y}$ \\
\hline $\mathrm{N}$ & 36,650 & 36,650 & 17,612 & 17,612 \\
\hline Adi. $\mathrm{R}^{2}$ & 0.0300 & 0.1200 & 0.0490 & 0.1250 \\
\hline
\end{tabular}




\section{Asymmetry test of institutional investor recognition in different market styles}

Due to the fact that the Chinese stock market was in different market states during the data period, in order to examine the relationship between corporate strategy deviation and institutional investor recognition in different market styles, we set three market states, that is, bull market, oscillator market, and shock market, which are defined in combination with the Shanghai Stock Composite Index, and then defined as follows.

$$
\begin{aligned}
\text { Bull }_{t} & =\left\{\begin{array}{ll}
1 & t \in A \mid n=19 \\
0 & t \in \text { other }
\end{array} ;\right. \\
\text { Bear }_{t} & =\left\{\begin{array}{ll}
1 & t \in B \mid n=15 \\
0 & t \in \text { other }
\end{array} ;\right. \\
\text { Shock }_{t} & =\left\{\begin{array}{ll}
1 & t \in C \mid n=23 \\
0 & t \in \text { other }
\end{array},\right.
\end{aligned}
$$

where, $B u l_{t}$ in Equation (6) refers to the bull market dummy variable, set $A=\{06.1-07.3$; 09.1-09.2; 14.3-15.2; 16.3-17.4 $n=19\}$ (time format is year-quarter); Bear ${ }_{t}$ in Equation (7) represents the bear market dummy variable, set $B=\{07.4-08.4 ; 10.1-10.2 ; 15.3-16.2 ; 18.1-$ $18.4 \mid n=15\}$; and Shock ${ }_{t}$ in Equation (8) refers to the shock market dummy variable, set $C=\{10.3-14.2 ; 19.1-20.1 \mid n=23\}$. The three dummy variables that characterize the market state and the two types of institutions interacting with them are substituted into the model, and tested as moderating variables in groups. As shown in Table 9, the explanatory variables are distinguished as follows: the models of (1) and (4) refer to the explanatory variable, the moderating variables and market state cross term under bull market; while the models of (2) and (5) refer to the explanatory variable, the moderating variables and market state cross term under bear market; and the models of (3) and (6) refer to the explanatory variable, the moderating variables and market state cross term under shock market.

Based on the analysis of the results in Table 9, in a bull market, institutional investors are generally optimistic and indifferent to deviations in the strategy deviation of listed companies, however, the head or conglomerate group of institutional investors is more sensitive. The negative effect is lower than the average of the benchmark regression, and the moderating effect is positive in the optimistic state of the market. In contrast, in a bear market, institutional investors generally remain insensitive to the deviations in the strategy deviation of listed companies, however, the interaction term results are positive, indicating that if deviations in the strategy deviation of listed companies occur in a bear market, instead, they are interpreted by most institutions as positive strategies for the emergence of positive moderating effects, i.e., positive recognition. On the other hand, the head or conglomerate group of institutional investors still maintains a negative effect, both in terms of explanatory variables and the moderating effect of the market state. This shows that institutional investors may be more sober. In a shock market, the institutional investors are cautious in most cases due to market instability, showing a negative moderating effect of market dynamics, however, the head or conglomerate group of institutional investors still significantly disapproves of the bias in corporate strategy deviation, which is independent of the moderating effect. In conclusion, the differences in corporate strategy deviation across market styles are asymmetric in terms of institutional investor recognition. Hypothesis 4 is tested. 
Table 9. Moderating role of market state - asymmetries in strategy deviation of firms and institutional investor recognition

\begin{tabular}{|c|c|c|c|c|c|c|}
\hline Variables & Groupown $_{i, t}$ & Groupown $_{i, t}$ & Groupown $_{i, t}$ & ${\text { Group } G N_{i, t}}$ & ${\text { Group } G N_{i, t}}$ & Group $N_{i, t}$ \\
\hline & (1) & (2) & (3) & (4) & (5) & (6) \\
\hline$D S_{i, t}$ & $\begin{array}{c}-0.0021 \\
(-1.1819)\end{array}$ & $\begin{array}{c}-0.0027 \\
(-1.5374)\end{array}$ & $\begin{array}{c}-0.0019 \\
(-1.0617)\end{array}$ & $\begin{array}{c}-0.0027^{* * *} \\
(-4.6320)\end{array}$ & $\begin{array}{l}-0.0012^{\star} \\
(-1.8279)\end{array}$ & $\begin{array}{l}-0.0019^{\star *} \\
(-2.3559)\end{array}$ \\
\hline$D S_{i, t} \times B u l l_{i, t}$ & $\begin{array}{c}-0.0004 \\
(-0.9198)\end{array}$ & & & $\begin{array}{c}0.0023^{* * *} \\
(4.5892)\end{array}$ & & \\
\hline$D S_{i, t} \times$ Bear $_{i, t}$ & & $\begin{array}{c}0.0017^{* * *} \\
(3.2752)\end{array}$ & & & $\begin{array}{c}-0.0027^{\star * *} \\
(-5.8704)\end{array}$ & \\
\hline$D S_{i, t} \times$ Shock $_{i, t}$ & & & $\begin{array}{l}-0.0011^{*} \\
(-1.6573)\end{array}$ & & & $\begin{array}{c}-0.0001 \\
(-0.1655)\end{array}$ \\
\hline Constant & $\begin{array}{c}-0.0389^{* * *} \\
(-2.7986)\end{array}$ & $\begin{array}{c}-0.0386^{* * *} \\
(-2.7779)\end{array}$ & $\begin{array}{c}-0.0391^{* * *} \\
(-2.8176)\end{array}$ & $\begin{array}{l}-0.0522^{* * *} \\
(-10.1716)\end{array}$ & $\begin{array}{l}-0.0521^{* * *} \\
(-10.1958)\end{array}$ & $\begin{array}{l}-0.0513^{* * *} \\
(-10.0553)\end{array}$ \\
\hline Controls & $\mathrm{Y}$ & $\mathrm{Y}$ & $\mathrm{Y}$ & $\mathrm{Y}$ & $\mathrm{Y}$ & $\mathrm{Y}$ \\
\hline $\mathrm{N}$ & 54,262 & 54,262 & 54,262 & 54,262 & 54,262 & 54,262 \\
\hline Adi. $R^{2}$ & 0.0710 & 0.0710 & 0.0710 & 0.1280 & 0.1280 & 0.1270 \\
\hline
\end{tabular}

\section{Stability test}

To ensure the reliability of the main results of this paper, the following stability tests were mainly conducted.

\subsection{Holding network clustering algorithm adjustment}

Instead of the algorithm for GN clustering in the stability test described previously, the equally computationally efficient Louvain algorithm, proposed by Blondel et al. (2008), is applied to solve the community learning clustering problem, which is a heuristic algorithm based on modularity optimization. The process of cutting a complex network into communities by this method is called modularity. Thus, the physical meaning of modularity is the difference between the number of connected edges of nodes in a community and the number of edges under random conditions. Specifically, if $i$ denotes a node, then $k_{i}$ denotes the weights of all edges connected to node $i$. The first step involves the computation in which each vertex is treated as a community, and the number of communities is the same as that of vertices. In the second step, each vertex is merged with its neighboring vertices in turn, and their modularity gain is calculated to be greater than 0 . In the case that it is greater than 0 , the node is put into the community of the neighboring nodes. Iterate the second step until the algorithm is stable, i.e., the communities to which all vertices belong no longer change. In the third step, all nodes of each community are compressed into one node, and the weights of the points within the community are transformed into the weights of the new node ring. Besides, the weights between communities are transformed into the weights of the new node edges. Then, the above calculations are repeated until the algorithm is stable, as shown in Figure 5.

Figure 5 shows an example, where each node is a separate community in the initial calculation of the first layer of graph clustering, and node $B$ is used as a community to cluster 


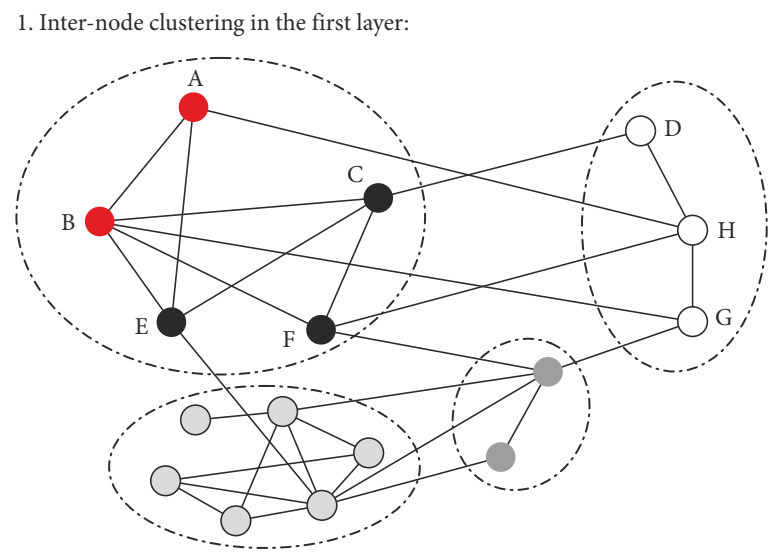

2. Inter-community clustering at the second level:

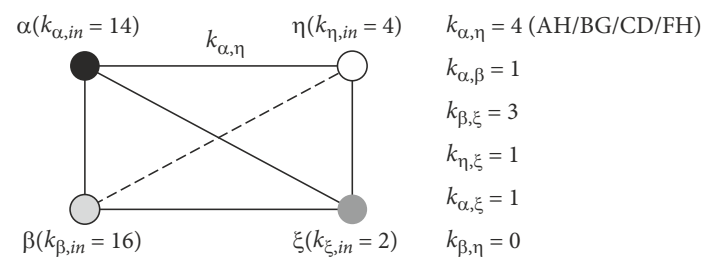

Figure 5. Example of Louvain's algorithm

node $A$. In the judgment, the undirected $\frac{1}{2} k_{i, \text { in }}$ is $1(A B), \frac{\sum_{\text {all }}}{2 m}$ is $\frac{5}{m}(B A, B C, B E, B F, B G)$, $k_{i}(A B, A E, A H)$ is $3, \sum k_{i} / m$ is less than 1 , the gain function $\Delta Q$ is positive, and node $A$ can be merged into community $B$. In this way, all node communities are traversed. The second layer is computed to reduce the communities into clusters forming classes of nodes $\alpha, \beta, \eta$, $\xi ; k_{i, \text { in }}$ is the weight sum of the self-loop edges of the communities reduced into clusters. For the connection between nodes of class $k_{i, j}$. The second layer is converted to the inner loop iteratively calculated to the modularity degree $Q$ stable.

In this paper, when the algorithm is replaced, as shown in (1) of Table 10, there is still a significant negative relationship between the listed companies' strategy deviation and institutional investors' cluster recognition.

\subsection{Adjustment test of listed companies' strategy deviation algorithm}

As mentioned before, since there are few separately disclosed data on advertising expenses and R\&D expenses for Chinese listed companies, the cost of sales and net intangible assets instead of advertising expenses and R\&D expenses are used in this paper to take approximate values, respectively. In the test of stability, the above two dimensions are removed to get the new $D S_{i, t}$ calculated by applying the four dimensions. Besides, the regressions are conducted, and the test results are shown in (2)-(3) of Table 10, and the change of the algorithm has no impact on the conclusion. 
Table 10. Institutional investor approval clustering algorithm adjustment and listed company strategy deviation algorithm adjustment test

\begin{tabular}{|l|c|c|c|}
\hline \multirow{2}{*}{ Variables } & Groupown $_{i, t}$ & Groupown $_{i, t}$ & GroupGN $_{i, t}$ \\
\cline { 2 - 4 } & $(1)$ & $(2)$ & $(3)$ \\
\hline$D S_{i, t}$ & $-0.0008^{\star}$ & $-0.0034^{*}$ & $-0.0020^{\star * *}$ \\
& $(-1.8471)$ & $(-1.9545)$ & $(-3.0433)$ \\
\hline $\mathrm{N}$ & 54,262 & 54,262 & 54,262 \\
\hline Constant & $-0.0371^{\star * \star}$ & $-0.0241^{\star}$ & $-0.0512^{\star * *}$ \\
& $(-10.4760)$ & $(-1.8697)$ & $(-10.5646)$ \\
\hline $\mathrm{N}$ & 54,262 & 54,262 & 54,262 \\
\hline Adi. $\mathrm{R}^{2}$ & 0.0260 & 0.0450 & 0.1210 \\
\hline
\end{tabular}

\subsection{Adjustment test for the definition of long position}

The benchmark model uses a liquid stock position of $1 \%$, and the position percentage is increased to $3 \%, 5 \%, 7 \%$ and $10 \%$ respectively to reconstruct the financial complex network, thereby measuring the general approval of institutional investors and the clustered approval of institutional investors. The regression results are shown in the models from (1)-(8) in Table 11, and the test results show that when the definition of heavy position is adjusted to $3 \%$, despite the change in the holding network, the listed companies show a bias in strategy deviation, and the institutional investors will still disapprove. However, when we continue to increase the threshold limit of outstanding shareholdings by two percentage, generally to $5 \%, 7 \%$ and $10 \%$ respectively, the data are not practically significant, and not enough in the overall regression due to the fact that the network becomes increasingly sparse based on the low relative shareholdings of institutional investors generally. The head institutional investors, on the other hand, have a relatively high relative shareholding. And although the degree of negative impact is decreasing, the clustering endorsement remains statistically significant at the $1 \%$ Statistical level. As the proportion of outstanding shares held by institutional investors increases, the coefficient of the regression generally becomes smaller. Most institutional investors are less and less concerned with corporate strategic deviations and operational risks, and may be more concerned with investment hotspots and market themes or its own

Table 11. Adjustments to the definition of long position

\begin{tabular}{|c|c|c|c|c|c|c|c|c|}
\hline Variables & $\begin{array}{c}G_{p o w n}, t \\
3 \%\end{array}$ & $\begin{array}{c}G p G N_{i, t} \\
3 \%\end{array}$ & $\begin{array}{c}G p o w n_{i, t} \\
5 \%\end{array}$ & $\begin{array}{c}G p G N_{i, t} \\
5 \%\end{array}$ & $\begin{array}{c}G_{p o w n} n_{i, t} \\
7 \%\end{array}$ & $\begin{array}{c}G p G N_{i, t} \\
7 \%\end{array}$ & $\begin{array}{c}G_{p o w} n_{i, t} \\
10 \%\end{array}$ & $\begin{array}{c}G p G N_{i, t} \\
10 \%\end{array}$ \\
\hline & (1) & (2) & (3) & (4) & (5) & (6) & (7) & (8) \\
\hline$D S_{i, t}$ & $\begin{array}{l}-0.0032^{*} \\
(-1.8548)\end{array}$ & $\begin{array}{c}-0.0020^{* * *} \\
(-3.1923)\end{array}$ & $\begin{array}{c}-0.0017 \\
(-1.0325)\end{array}$ & $\begin{array}{c}-0.0018^{\star * *} \\
(-2.9159)\end{array}$ & $\begin{array}{c}-0.0021 \\
(-1.4160)\end{array}$ & $\begin{array}{c}-0.0016^{\star * *} \\
(-2.7248)\end{array}$ & $\begin{array}{c}-0.0008 \\
(-1.0833)\end{array}$ & $\begin{array}{c}-0.0015^{\star * *} \\
(-2.6870)\end{array}$ \\
\hline Constant & $\begin{array}{l}-0.0252^{\star *} \\
(-2.0313)\end{array}$ & $\begin{array}{c}-0.0432^{* * *} \\
(-9.2748)\end{array}$ & $\begin{array}{c}-0.0409^{* * *} \\
(-3.3193)\end{array}$ & $\begin{array}{c}-0.0355^{\star * *} \\
(-7.6496)\end{array}$ & $\begin{array}{l}-0.0229^{* *} \\
(-2.3477)\end{array}$ & $\begin{array}{c}-0.0355^{* * *} \\
(-8.0223)\end{array}$ & $\begin{array}{c}-0.0209^{* * *} \\
(-4.1812)\end{array}$ & $\begin{array}{c}-0.0296^{* * *} \\
(-7.1799)\end{array}$ \\
\hline Controls & $\mathrm{Y}$ & $\mathrm{Y}$ & $\mathrm{Y}$ & Y & Y & Y & $\mathrm{Y}$ & Y \\
\hline $\mathrm{N}$ & 54,262 & 54,262 & 54,262 & 54,262 & 54,262 & 54,262 & 54,262 & 54,262 \\
\hline Adi. $R^{2}$ & 0.0380 & 0.1180 & 0.0520 & 0.1240 & 0.0250 & 0.1080 & 0.0420 & 0.0990 \\
\hline
\end{tabular}


strategy and risk, but investment groups or head institutions are always more concerned with corporate strategic deviations. This is also in line with the investment characteristics of the Chinese capital market. The result also illustrates the stability of the validation findings from another perspective.

\section{Conclusions and discussion}

Scholars have used network topology properties to study microstructure in financial markets with good results in recent years. In order to obtain better data, we use financial network holdings and clustering to measure the degree of institutional investor recognition, instead of using a single perspective to measure shareholding ratios, position openings, and turnover rates. The capital market is an interconnected, symbiotic and interdependent ecological community, therefore, the shareholding ratio of one institution is not able to indicate the degree of recognition of the institution itself. In view of this, this paper constructs a complex network, in this manner to provide a more accurate description from the universal and group perspectives of the institution. Till now, no literature has been found to use this approach to study issues related to this thesis. While most previous literature has tested the direct impact of strategic information on corporate stock prices or market values, with less attention paid to the perspective of how strategic information at the internal decision-making level of firms affects the attention and recognition of capital market investors. In this paper, empirical evidence from a new perspective is provided on the of strategic information for the recognition of institutional investors in the capital market.

Through our findings, which explain our observations and are in line with existing similar views of the final results, although the specific methods we used, the details of the study are not the same and we have summarised the theoretical and practical implications of the work.

The contribution of this study to the literature is: we construct the quarterly panel data from 2006 to 2020 to study the heterogeneity and asymmetry of institutional investors' recognition of strategic differences of listed companies. It is found that the greater the strategy deviation of listed firms, the lower the institutional investor's endorsement of the decision to hold outstanding shares of the firm. And the group endorsement of institutional clusters in the capital market is more significant than other institutional investors. Both are insensitive to financial and financing-driven strategy deviation, while most institutional investors are more concerned with balance sheet matters, and the institutional clusters are more concerned with income statement matters. Though the institutional investors cannot accept a large deviation in strategy deviation of listed state-owned enterprises, they are insensitive to the deviations in strategy deviation of private and foreign companies, etc., when their operating styles are contrary to industry averages. In the case that there are different style changes in the overall market sentiment, institutional investors also appear to show different shareholding recognitions, and their specific moderating effect is asymmetric. In short, institutional investors, as external stakeholders, have different attitudes towards strategic deviation in different strategic areas, different nature of enterprises and different market styles. But on the whole, it shows a negative attitude. The reason may be that enterprises adopt unconventional strategic route, which may increase business risks and operating costs, resulting in unstable 
valuation of the capital market and value fluctuations; at the same time, due to asymmetric information, institutional investors cannot carefully distinguish the other side's strategic deviation from "reform and innovation" or "deviant", but for risk considerations, they do not recognize this strategy Deviation.

Therefore, in terms of corporate strategy designation and practice, we believe that: Firstly, the relevant state departments further regulate the disclosure of corporate strategy information, guide enterprises to improve the quantity of strategic risk information disclosure, thus reducing the degree of risk and information asymmetry brought by corporate strategy differences, and mitigating the adverse economic consequences of corporate strategy differences. Secondly, capital market participants should have a more comprehensive understanding of the economic consequences of strategic choices, so as to avoid investment losses due to information asymmetry, while in the meantime, recognize the core competitiveness of strategic choices and have a certain understanding of their riskiness. Most important of all, when planning the strategic layout, the enterprises should fully realize the operational risks that the strategy may face if it deviates from the conventional way of the industry, attach importance to the disclosure of strategic information, improve the off-balance sheet disclosure, do a good job in publicity and interpretation, and alleviate the information asymmetry of the capital market. Improve the assessment rating of corporate information disclosure, and alleviate the adverse economic consequences of corporate strategic differences.

Of course, there are still inevitable limitations to this work, and the existence of limitations also means that future research will be full of promise. In particular, they are as follows.

Firstly, we have focused our research on the issue of the relationship between corporate strategy deviations and external institutional investor recognition. As the secondary market for our securities has a strong speculative flavor, we see this endorsement and increase in holdings as an external force, but we cannot exclude that some of the related parties are privy to inside information. The specific mechanics of that segment are beyond the scope of this investigation, but the issue is equally worthy of depth.

Secondly, we have made strategic deviation an important part of the work, but its opposing view, strategic integration, is not mentioned in the empirical session. While a hasty mention would make the objective of the study unclear, what is the attitude of institutional investors towards strategic integration in the context of network structures? Are the answers to these two related questions diametrically opposed? This is also a question worth pondering.

Finally, it would be a new perspective if other techniques were used to move away from institutional investors' endorsement of corporate strategic deviations and instead focus on whether they are "reform and innovation" or "deviation from the norm". Its relevance to this paper is that since institutional investors do not recognize strategic deviations, it is all the more important for the corporate authorities to be sure that they are "reforming and innovating" and following their own path, rather than "deviating" and being abandoned by the financing market.

\section{Funding}

This work was supported by the $<$ Social Science Planning and Research Project of Shandong Province> under Grant [number 21BTJJ01]. 


\section{Author contributions}

Chun-Yan Lin conceived the study and were responsible for the design and development of the data analysis. Jia Liu was responsible for data collection, concrete analysis and wrote the first draft of the article. Pei-De Liu was responsible for organizing ideas, revising, touching up and correcting the manuscript.

\section{Disclosure statement}

Authors have no conflict of interest to declare.

\section{References}

Algaeed, A. H. (2021). Capital market development and economic growth: an ARDL approach for Saudi Arabia, 1985-2018. Journal of Business Economics and Management, 22(2), 388-409. https://doi.org/10.3846/jbem.2020.13569

Bates, T. W., Kahle, K. M., \& Stulz, R. M. (2009). Why do U.S. firms hold so much more cash than they used to? Journal of Finance, 64(5), 1985-2021. https://doi.org/10.1111/j.1540-6261.2009.01492.x

Benner, M. J. (2010). Securities analysts and incumbent response to radical technological change: Evidence from digital photography and internet telephony. Organization Science, 21(1), 42-62. https://doi.org/10.1287/orsc.1080.0395

Bentley, K. A., Omer, T. C., \& Sharp, N. Y. (2013). Business strategy, financial reporting irregularities, and audit effort. Contemporary Accounting Research, 30(2), 780-817. https://doi.org/10.1111/j.1911-3846.2012.01174.x

Blanc Alquier, A. M., \& Lagasse Tignol, M. H. (2006). Risk management in small- and medium-sized enterprises. Production Planning \& Control, 17(3), 273-282. https://doi.org/10.1080/09537280500285334

Blondel, V. D., Guillaume, J. L., Lambiotte, R., \& Lefebvre, E. (2008). Fast unfolding of communities in large networks. Journal of Statistical Mechanics: Theory and Experiment, 10. https://doi.org/10.1088/1742-5468/2008/10/P10008

Buzzell, R. D., \& Gale, B. T. (1987). The PIMS principles: linking strategy to performance. Journal of Marketing, 53(2), 126-129. https://doi.org/10.1177/002224298905300210

Cappa, F., Cetrini, G., \& Oriani, R. (2020). The impact of corporate strategy on capital structure: Evidence from Italian listed firms. The Quarterly Review of Economics and Finance, 76, 379-385. https://doi.org/10.1016/j.qref.2019.09.005

Cazavan-Jeny, A., \& Jeanjean, T. (2006). The negative impact of R\&D capitalization: A value relevance approach. European Accounting Review, 15(1), 37-61. https://doi.org/10.1080/09638180500510384

Carpenter, M. A. (2000). The price of change: The role of CEO compensation in strategic variation and deviation from industry strategy norms. Journal of Management, 26(6), 1179-1198. https://doi.org/10.1177/014920630002600606

Chatterjee, A., \& Hambrick, D. C. (2007). It's all about me: Narcissistic chief executive officers and their effects on company strategy and performance. Administrative Science Quarterly, 52(3), 351-386. https://doi.org/10.2189/asqu.52.3.351

Chauhan, G. S., \& Huseynov, F. (2016). Corporate financing and target behavior: New tests and evidence. Journal of Corporate Finance, 48, 840-856. https://doi.org/10.1016/j.jcorpfin.2016.10.013

Chebbi, H., Yahiaoui, D., Sellami, M., Papasolomoud, I., \& Melanthiou, Y. (2020). Focusing on internal stakeholders to enable the implementation of organizational change towards corporate entrepreneurship: A case study from France. Journal of Business Research, 119, 209-217.

https://doi.org/10.1016/j.jbusres.2019.06.003 
Chen, M. J., \& Miller, D. (1994). Competitive attack, retaliation and performance: An expectancy-valence framework. Strategic Management Journal, 15(2), 85-102. https://doi.org/10.1002/smj.4250150202

Chen, T. Q., He, J. M., \& Li, X. D. (2017). An evolving network model of credit risk contagion in the financial market. Technological and Economic Development of Economy, 23(1), 22-37. https://doi.org/10.3846/20294913.2015.1095808

Chen, T., \& Lin, C. (2017). Does information asymmetry affect corporate tax aggressiveness? Journal of Financial \& Quantitative Analysis, 52(5), 2053-2081. https://doi.org/10.1017/S0022109017000576

Das, S., Sen, P. K., \& Sengupta, S. (1998). Impact of strategic alliances on firm valuation. Academy of Management Journal, 41(1), 27-41. https://doi.org/10.2307/256895

DiMaggio, P. J., \& Powell, W. W. (1983). The iron cage revisited: Institutional isomorphism and collective rationality in organizational fields. American Sociological Review, 48(2), 147-160. https://doi.org/10.2307/2095101

DiMaggio, P. J., \& Powell, W. W. (1991). Introduction. In The new institutionalism in organizational analysis. University of Chicago Press.

Doukas, J., \& Switzer, L. (1992). The stock market's valuation of R\&D spending and market concentration. Journal of Economics \& Business, 44(2), 95-114. https://doi.org/10.1016/0148-6195(92)90009-Y

Dvorsk, J., Belas, J., Gavurová, B., \& Brabenec, T. (2021). Business risk management in the context of small and medium-sized enterprises. Economic Research-Ekonomska Istraživanja, 34(1), 1690-1708. https://doi.org/10.1080/1331677X.2020.1844588

Gao, J., Liang, Z., Shang, J., \& Xu, Z. (2020). Remanufacturing with patented technique royalty under asymmetric information and uncertain markets. Technological and Economic Development of Economy, 26(3), 599-620. https://doi.org/10.3846/tede.2019.10287

Geletkanycz, M. A., \& Hambrick, D. C. (1997). The external ties of top executives: implications for strategic choice and performance. Administrative Science Quarterly, 42(4), 654-681. https://doi.org/10.2307/2393653

Habib, A., Hasan, M. M., \& Jiang, H. (2017). Stock price crash risk: review of the empirical literature. Accounting \& Finance, 58, 211-251. https://doi.org/10.1111/acfi.12278

Haunschild, P. R. (1993). Interorganizational imitation: the impact of interlocks on corporate acquisition activity. Administrative Science Quarterly, 38(4), 564-592. https://doi.org/10.2307/2393337

Haveman, H. A. (1993). Follow the leader: mimetic isomorphism and entry into new markets. Administrative Science Quarterly, 38(4), 593-627. https://doi.org/10.2307/2393338

Henry, A. O., Osei, D., \& Franco, M. (2019). Leverage deviations and acquisition probability in the UK: The moderating effect of firms' internal capabilities and deal diversification potential. European Management Review, 16(4), 1059-1077. https://doi.org/10.1111/emre.12307

Higgins, D., Omer, T. C., \& Phillips, J. D. (2015). The influence of a firm's business strategy on its tax aggressiveness. Contemporary Accounting Research, 32(2), 674-702. https://doi.org/10.1111/1911-3846.12087

Hutton, A. P., Marcus, A. J., \& Tehranian, H. (2009). Opaque financial reports, $\mathrm{R}^{2}$, and crash risk. Journal of Financial Economics, 94(1), 67-86. https://doi.org/10.1016/j.jineco.2008.10.003

Ittner, C. D., Larcker, D. F., \& Rajan, M. V. (1997). The choice of performance measures in annual bonus contracts. The Accounting Review, 72(2), 231-255. https://www.jstor.org/stable/248554

Yin, K. D., Liu, Z., Huang, C., \& Liu, P. D. (2020). Topological structural analysis of China's new energy stock market: A multi-dimensional data network perspective. Technological and Economic Development of Economy, 26(5), 1030-1051. https://doi.org/10.3846/tede.2020.12723

Jin, L., \& Myers, S. C. (2006). $\mathrm{R}^{2}$ around the world new theory and new tests. Journal of Financial Economics, 79(2), 257-292. https://doi.org/10.1016/j.jfineco.2004.11.003 
Keating, A. S., \& Zimmerman, J. L. (1999). Depreciation-policy changes: Tax, earnings management, and investment opportunity incentives. Journal of Accounting \& Economics, 28(3), 359-389. https://doi.org/10.1016/S0165-4101(00)00004-5

Kinney, Jr. W. R., \& McDaniel, L. S. (1989). Characteristics of firms correcting previously reported quarterly earnings. Journal of Accounting and Economics, 11(1), 71-93. https://doi.org/10.1016/0165-4101(89)90014-1

Kothari, P., Patel, S., Brown, P., Obara, L., \& O’Malley, S. (2002). A prospective double-blind randomized controlled trial comparing the suitability of KTP laser tonsillectomy with conventional dissection tonsillectomy for day case surgery. Clinical Otolaryngology, 27(5), 369-373. https://doi.org/10.1046/j.1365-2273.2002.00596.x

Kothari, S. P., Shu, S., \& Wysocki, P. D. (2009). Do managers withhold bad news? Journal of Accounting Research, 47(1), 241-276. https://doi.org/10.1111/j.1475-679X.2008.00318.x

Lara, J. M. G., Osma, B. G., \& Penalva, F. (2011). Conditional conservatism and cost of capital. Review of Accounting Studies, 16(2), 247-271. https://doi.org/10.1007/s11142-010-9133-4

Li, D. F., \& Liu, P. D. (2020). Big data and intelligent decision methods in economy, innovation and sustainable development. Technological and Economic Development of Economy, 26(5), 970-973. https://doi.org/10.3846/tede.2020.13354

Li, R., Cui, Y., \& Zheng, Y. (2021). The impact of corporate strategy on enterprise innovation based on the mediating effect of corporate risk-taking. Sustainability, 13(3), 1023. https://doi.org/10.3390/su13031023

Miles, R. E., \& Snow, C. C. (2003). Organizational strategy, structure, and process. Stanford University Press.

Miles, R. E., Snow, C. C., Meyer, A. D., \& Coleman, H. J. (1978). Organizational strategy, structure, and process. The Academy of Management Review, 3(3), 546-562. https://doi.org/10.5465/amr.1978.4305755

Newman, M. E. J., \& Girvan, M. (2004). Finding and evaluating community structure in networks. Physical Review E, 69(2), 026113. https://doi.org/10.1103/PhysRevE.69.026113

Pareek, A. (2012). Information networks: Implications for mutual fund trading behavior and stock returns. SSRN Electronic Journal, 2. https://doi.org/10.2139/ssrn.1361779

Park, J. I., \& Hee, J. S. (2017). The relation between corporate tax aggressiveness and future financial performance. Journal of Taxation and Accounting, 18(3), 145-182. https://doi.org/10.35850/KJTA.18.3.06

Prahalad, C. K., \& Hamel, G. (1990). The core competence of the corporation. Harvard Business Review, 68(3), 275-292. https://doi.org/10.1007/3-540-30763-X_14

Rajagopalan, N. (1997). Strategic orientations, incentive plan adoptions, and firm performance: Evidence from electric utility firms. Strategic Management Journal, 18(10), 761-785. https://doi.org/10.1002/(SICI)1097-0266(199711)18:10<761::AID-SMJ906>3.0.CO;2-2

Rajagopalan, N., \& Spreitzer, G. M. (1997). Toward a theory of strategic change: A multi-lens perspective and integrative framework. Academy of Management Review, 22(1), 48-79. https://doi.org/10.5465/amr.1997.9707180259

Salehi, M., \& Arianpoor, A. (2021). The relationship between business strategy and management entrenchment. International Journal of Productivity and Performance Management. https://doi.org/10.1108/IJPPM-06-2020-0288

Salehi, M., \& Ghasempour, F. (2021). Material internal control weakness with intangible assets, capital structure and commercial risk. Management Research Review, 44(7), 1059-1082. https://doi.org/10.1108/MRR-06-2020-0335 
Salehi, M., Dashtbayaz, M. L., \& Abdulhadi, K. H. (2020a). The relationship between managerial entrenchment and firm risk-taking on social responsibility disclosure. Journal of Public Affairs. https://doi.org/10.1002/pa.2511

Salehi, M., Naeini, A., \& Rouhi, S. (2020b). The relationship between manager' narcissism and overconfidence on corporate risk-taking. The TQM Journal. https://doi.org/10.1108/TQM-07-2020-0168

Shaikh, I. A., \& O'Connor, G. C. (2020). Understanding the motivations of technology managers in radical innovation decisions in the mature R\&D firm context: An agency theory perspective. Journal of Engineering and Technology Management, 55, 101553. https://doi.org/10.1016/j.jengtecman.2020.101553

Suijs, J. (2008). On the value relevance of asymmetric financial reporting policies. Journal of Accounting Research, 46(5), 1297-1321. https://doi.org/10.1111/j.1475-679X.2008.00309.x

Tang, J., Crossan, M., \& Rowe, W. G. (2011). Dominant CEO, deviant strategy, and extreme performance: the moderating role of a powerful board. Journal of Management Studies, 48(7), 1479-1503. https://doi.org/10.1111/j.1467-6486.2010.00985.x

Wen, J., Feng, G. F., Chang, C. P., \& Feng, Z. Z. (2018). Stock liquidity and enterprise innovation: New evidence from China. European Journal of Finance, 24(9), 683-713. https://doi.org/10.1080/1351847X.2017.1347573

Zhao, E. Y., Fisher, G., Lounsbury, M., \& Miller, D. (2017). Optimal distinctiveness: broadening the interface between institutional theory and strategic management. Strategic Management Journal, 38(1), 93-113. https://doi.org/10.1002/smj.2589

Zhou, Y. M., \& Wan, X. (2017). Product variety, sourcing complexity, and the bottleneck of coordination. Strategic Management Journal, 38(8), 1569-1587. https://doi.org/10.1002/smj.2619

Ziolo, M., Bak, I., \& Cheba, K. (2021). The role of sustainable finance in achieving Sustainable Development Goals: Does it work? Technological and Economic Development of Economy, 27(1), 45-70. https://doi.org/10.3846/tede.2020.13863

Zuckerman, E. W. (2016). Optimal distinctiveness revisited: An integrative framework for understanding the balance between differentiation and conformity in individual and organizational identities. Oxford University Press. https://doi.org/10.1093/oxfordhb/9780199689576.013.22 